\title{
Legitimate Actors of International Law-Making: Towards a Theory of International Democratic Representation
}

\author{
Samantha Besson, José Luis Martí
}

\section{- To cite this version:}

Samantha Besson, José Luis Martí. Legitimate Actors of International Law-Making: Towards a Theory of International Democratic Representation. Jurisprudence, Taylor \& Francis, 2018, 9 (3), pp.504540. 10.1080/20403313.2018.1442256 . hal-02516256

\section{HAL Id: hal-02516256 \\ https://hal.archives-ouvertes.fr/hal-02516256}

Submitted on 3 May 2020

HAL is a multi-disciplinary open access archive for the deposit and dissemination of scientific research documents, whether they are published or not. The documents may come from teaching and research institutions in France or abroad, or from public or private research centers.
L'archive ouverte pluridisciplinaire HAL, est destinée au dépôt et à la diffusion de documents scientifiques de niveau recherche, publiés ou non, émanant des établissements d'enseignement et de recherche français ou étrangers, des laboratoires publics ou privés. 


\title{
Legitimate actors of international law-making: towards a theory of international democratic representation
}

\author{
Samantha Besson ${ }^{a}$ and José Luis Marti ${ }^{b}$ \\ ${ }^{a}$ Chair of Public International Law and European Law, University of Fribourg, Switzerland; ${ }^{b}$ Department of \\ Law, Pompeu Fabra University, Barcelona, Spain
}

\begin{abstract}
This article addresses the identity of the legitimate actors of international law-making from the perspective of democratic theory. It argues that both states or state-based international organisations, and civil society actors should be considered complementary legitimate actors of international law-making. Unlike previous accounts, our proposed model of representation, the Multiple Representation Model, is based on an expanded, democratic understanding of the principle of state participation: it is specifically designed to palliate the democratic deficits of more common versions of the Principle of State Consent. Second, it endorses a qualified version of the Principle of Civil Society Participation, one that is much more restrictive and more critical of the democratic defects of civil society actors than most of its current supporters. Finally, it reveals how the democratic strengths and deficits of both models are best approached as mirroring one another and need to be combined in a complex account of representation.
\end{abstract}

\section{KEYWORDS}

International law; lawmaking; actors; democratic legitimacy; representation; states; civil society; state consent

\section{Introduction}

Imagine a Spanish citizen living in Barcelona, concerned about climate change and its potential devastating global effects, and shocked about how ineffective the international system has been so far in articulating a strong and adequate reaction aiming at stopping or vastly reducing further emissions and preventing future harms. This citizen takes this fact to be a tremendous failure of the current international decision-making system. $\mathrm{He}$ blames the Spanish government for not having taken more decisive steps in that direction, but he also believes that climate change policies should mainly come from the international level, since it is obvious that a global action is needed to have any real impact. $\mathrm{He}$ is suspicious that certain private actors might be illegitimately trying to paralyse any initiative at that level. This Spanish citizen wonders what concrete actors he could complain to, whether all the actors who have been involved in the international system were legitimate to intervene, and, more importantly, he wonders who should represent his views and claims in international decision-making processes and how.

CONTACT Samantha Besson samantha.besson@unifr.ch 0 Chair of Public International Law and European Law, University of Fribourg, Av. de Beauregard 11, Fribourg 1700, Switzerland 
Think now of the case of a Chinese citizen living in Beijing, worried about the lack of democracy and the severe violations of human rights committed by the government in her country. That citizen blames her government for such evils, of course, and perhaps also her fellow citizens - and herself - for not doing enough to remove that government. However, she also thinks that the international legal system should take more active and effective steps to protect human rights and foster democracy globally, including in her country. She considers the lack of such measures as a tremendous failure of the current international system and feels that she has been let down. She wonders, for instance, whether the Chinese government, given that it is not democratic, should be considered a legitimate actor in that system. She is also concerned about who should represent her views and claims in international decision-making processes given that her government cannot do it properly.

These two citizens have complaints about how the international system is currently working. They are dissatisfied with it for different reasons, but they share a central concern about who should be allowed to intervene decisively in international lawmaking. They would like to know who is a legitimate actor in those law-making processes and who is not. And they aspire to identify who should represent their views and claims in them, in order to find out whom to blame for what they consider, respectively, as two tremendous failures in the international system.

International law theories have traditionally subscribed to what has been called a Statist Model, according to which states and state-based International Organisations (IOs) are the only legitimate actors in international law-making. On that model, the Spanish and the Chinese citizens in the previous examples have only their state and, more specifically, their state government to blame, or to request for a more adequate representation and defence of their views in existing processes of international law-making.

Of course, international law-making has become increasingly complex over time. Nowadays, indeed, the international law-making processes or sources of international law - treaties, custom, and general principles, and their judicial interpretations - are often combined with more sophisticated forms of law-making. ${ }^{1}$ More specifically, but not exclusively, the institutional actors of international law-making, namely, states and IOs, are operating today in a much wider arena that includes different kinds of nonstate actors, i.e. private actors coming from the so-called global civil society, and most notably NGOs, corporations, and private or hybrid networks. ${ }^{2}$ All these actors interact in multifarious ways, through a variety of forms and procedures and in diverse settings and contexts. The outcome of all those interactions amounts to a more global form of international law in terms of the actors involved in its making. ${ }^{3}$

\footnotetext{
'Samantha Besson and Jean d'Aspremont, 'Introduction' in Samantha Besson and Jean d'Aspremont (eds), Oxford Handbook on the Sources of International Law (OUP 2017); José Luis Martí, 'Sources and the Legitimacy of International Law' in Samantha Besson and Jean d'Aspremont (eds), Oxford Handbook on the Sources of International Law (OUP 2017).

${ }^{2}$ Anne Marie Slaughter, A New World Order (Princeton UP 2014); Mary Kaldor, Global Civil Society: An Answer to War (Polity Press 2003); John Keane, Global Civil Society? (CUP 2003); Alejandro Colás, International Civil Society: Social Movements in World Politics (Polity Press 2002).

${ }^{3}$ Because we approach issues of validity and legitimacy of international law as related and do not see the analytical question of what is international law as entirely distinct from the normative question of what is legitimate international law, we intentionally abstain from specifying the concept of international law and international law-making further at this stage. Unlike others (e.g. Joost Pauwelyn, Ramses Wessel and Jan Wouters [eds], Informal International Law-Making [OUP 2012]), therefore, we do not consider that a distinction between 'formal' and 'informal' international lawmaking (or, as a matter of fact, between 'hard' and 'soft' international legal norms) may be drawn descriptively before and without a normative discussion of the identity of the legitimate actors of international law-making.
} 
By actors of international law-making, we obviously mean international law-makers, that is, anyone who has an important or non-trivial influence on the determination of international law. Therefore, not everyone who intervenes in one way or another in that process becomes an actor in this sense. Assistants who type, translate, or edit linguistically a draft of a decision do intervene in the process, but have no significant influence in the determination of the result. Only those who can exert a significant influence act in the process in a non-trivial way, and can be considered actors. Finally, the sum of all the actors in a particular process of law-making constitutes the authors of such law. Consequently, the notion of 'actor' in a process of law-making is intrinsically related to the idea of an authorial intervention or, in other words, to the idea of authority in a descriptive sense. All the actors who actually intervene collectively in the law-making process in a nontrivial way become the authors of such law, and act as the authorities, in a descriptive sense, of such a legal system.

Faced with this plurality of actors intervening in current processes of international lawmaking, the question is who among those, and under what conditions, can legitimately claim to intervene in them, or, in other words, who among these authorities in the descriptive sense are also authorities in a normative sense. More concretely: who can legitimately speak in our name in the making of international law? Who can effectively represent the interests, views and claims, of Spanish and Chinese citizens? Given how crucial international law has become in our lives due to globalisation and other causes, this set of questions is of the utmost importance.

We start, in section 2, by explaining what we mean by political legitimacy. As we understand it, it refers to the questions of who has the right to rule (or the right to create legal norms, or participate in the creation of such norms) and how such a right to rule should be exerted in order to generate obligations for those subject to such rule. We assume that any plausible standard of legitimacy must be democratic. We identify democratic legitimacy with four basic principles, the most important one being the Principle of ultimate, effective popular control: an institution or a procedure of law-making is legitimate to the extent that it is kept under the ultimate, effective control of the people (or peoples) who is (or are) affected by it. Those people(s) can delegate their powers to representatives who can operate as the immediate actors involved in the law-making process, but only as long as they retain ultimate, effective control over what such representatives do. This turns the question of the legitimate actors of international law-making into one of legitimate representation: who can claim to be a legitimate representative of the people(s)' interests, views and claims in the international legal system?

In section 3, we explore the traditional response given to this question in international law theory, the so-called Statist Model (SM). We describe that model as monist, for it argues that there is ultimately only one kind of legitimate actors of international lawmaking: states (and state-based ${ }^{4}$ or state-like ${ }^{5}$ IOs). And we briefly characterise it as grounded in the Principle of State Consent (PSC), which has had a major influence in

\footnotetext{
${ }^{4}$ Of course, like states, IOs increasingly associate with other non-state actors in their international law-making practice. The difficulty with IOs is that their constitutive criteria and boundaries are even more contested than states, thereby making their delineations from non-state actors less clear. Jan Klabbers, An Introduction to International Organizations Law (3rd edn, CUP 2015).

${ }^{5}$ Some IOs, like the European Union (EU), have indeed developed what we consider as state-like democratic legitimacy to the extent that they have a people of citizens they grant political equality to, some direct participatory rights and parliamentary representation.
} 
traditional accounts of international law-making. In section 4, however, we analyse the shortcomings of this model from the perspective of democratic legitimacy. We provide a list of democratic deficits of the model, many of which have been highlighted by the specialised literature, including by some advocates of the SM itself.

Mostly as a response to the democratic shortcomings of the SM, many authors have since argued for a Dualist Model (DM) of legitimate actors of international lawmaking, which we characterise in section 5 as defending the incorporation into the decision-making process of actors other than states or state-based/state-like IOs. These other actors may be NGOs, corporations, unions, churches, etc. but they all share the feature of being private actors coming from global civil society. This model expands the SM by granting civil society a significant role in the international law-making process, and that role may be referred to as the Principle of Civil Society Participation (PCSP). That principle does not exclude the participation of states, but it weakens the PSC significantly. We agree with the supporters of the DM that the SM needs to be expanded in this way. However, the PCSP is far from being perfect from the perspective of democratic legitimacy, especially if the participation of civil society actors is not adequately qualified and constrained, and if their interaction with public actors is not properly balanced. In section 6, we identify the various democratic shortcomings of the DM, and conclude that the DM, at least in the way in which it has been presented in the literature, does not meet the requirements of democratic legitimacy.

We end, in section 7, by advancing our own model for the democratic legitimacy of international law-making. It is distinctive from the SM and the DM in several respects. First, it is based on an expanded, more democratic understanding of the PSC: it approaches it as a Principle of State Participation (PSP), that may or may not include consent, depending on the contexts and specific fora in which states operate, and it is specifically designed to overcome or palliate the democratic deficits of more common versions of the PSC. Second, the proposed model endorses a qualified version of the PCSP, one that is much more restrictive than that of most of its supporters and is designed to overcome its democratic shortcomings. Third, our argument reveals how the democratic strengths and deficits of both models are best approached as mirroring one another and need to be combined for mutual reinforcement in future accounts of the democratic legitimacy of international law-making. The PSP and the PCSP should therefore be combined into a complex framework of multiple representation, one in which people(s) from all around the world can find multiple legitimate representatives, public and private, that defend their interests in international law-making. This is what we call the Multiple Representation Model (MRM). It is multiple in at least two ways: in the specific combination of statist and civil society representatives, on the one hand, and in the combination, on each side, of many levels of representation, among both statist and civil society representatives, on the other. Finally, and accordingly, the MRM considers that different kinds of actors may be legitimate in different settings, regarding different issues and with different combinations, and that the requirements imposed on them are necessarily contextsensitive.

A caveat is in order at the outset of the argument. We view this article as a first exploration of the identity of the legitimate actors of international law-making. Accordingly, some of the issues broached deserve a more detailed treatment and will actually be addressed in depth in a series of separate articles. One should mention, for instance, the public/private 
divide in international law, the identification of the different contexts in which the right balance between public and private actors may be significantly different, of the concept of international democratic representation, and the idea of multiple sovereignty which underlies our argument. The strength of this first exploratory article, however, is to map the respective democratic merits and shortcomings of the two most common models of legitimate actors of international law-making, to show how they actually mirror one another, and to explain how their combination should work in order to overcome their democratic deficits.

\section{Democratic legitimacy and international representation}

What standard should one use to address the question of the legitimacy of actors as authors of international law-making? The idea of political legitimacy is complex. It has given rise to an extensive philosophical literature, but there is little consensus about its meaning, main features, and requirements. ${ }^{6}$ The same may be said about transposing the concept of political legitimacy to the international level and applying that one and same concept to both domestic and international political contexts. ${ }^{7}$ Scope precludes addressing most of those complexities in this article, and we will rely for that reason on a basic understanding of political legitimacy that many different accounts can agree on.

Political legitimacy, as we see it, is a normative property of institutions and procedures of public decision-making and law-creation that focuses on two related questions: who has the right to rule (or the right to create legal norms) and how it should be exerted in order to generate obligations for those subject to that rule. What the substantive content of such decisions or norms should be is an entirely different question, which we take to be a question of justice. ${ }^{8}$ When an institution or a decision-making process

\footnotetext{
${ }^{6}$ William Edmundson, 'State of the Art: The Duty to Obey the Law' (2004) 10 Legal Theory 215; Leslie Green, 'Legal Obligation and Authority' [2012] in The Stanford Encyclopaedia of Philosophy <https://plato.stanford.edu/entries/legalobligation> accessed 8 February 2018; Thomas Christiano, 'Democracy' [2015] in The Stanford Encyclopaedia of Philosophy https://plato.stanford.edu/archives/spr2015/entries/democracy/> accessed 8 February 2018; Thomas Christiano, 'Authority' [2013] in The Stanford Encyclopaedia of Philosophy https://plato.stanford.edu/entries/authority/> accessed 8 February 2018; Richard Dagger and David Lefkowitz, 'Political Obligation' [2014] in The Stanford Encyclopaedia of Philosophy https://plato.stanford.edu/entries/political-obligation/> accessed 8 February 2018.

${ }^{7}$ Samantha Besson, 'The Authority of International Law: Lifting the State Veil' (2009) 31 Sydney LR 343; Martí, 'Sources and the Legitimacy of International Law' (n 1); Allen Buchanan and Robert Keohane, 'The Legitimacy of Global Governance Institutions' (2006) 20 Ethics and International Affairs 405; Allen Buchanan, 'The Legitimacy of International Law' in Samantha Besson and John Tasioulas (eds), The Philosophy of International Law (OUP 2010); Thomas Christiano, 'The Legitimacy of International Institutions' in Andrei Marmor (ed), Routledge Companion to Philosophy of Law (Routledge 2012); Thomas Christiano, 'Democratic Legitimacy and International Institutions' in Samantha Besson and John Tasioulas (eds), The Philosophy of International Law (OUP 2010); Philip Pettit, 'Legitimate International Institutions: A Neorepublican Perspective' in Samantha Besson and John Tasioulas (eds), The Philosophy of International Law (OUP 2010); John Tasioulas, 'The Legitimacy of International Law' in Samantha Besson and John Tasioulas (eds), The Philosophy of International Law (OUP 2010).

${ }^{8}$ It is very important to distinguish conceptually between legitimacy and justice, the two main tasks of political philosophy. Even if they disagree about the details, this is a distinction present in the views of important contemporary political philosophers like John Rawls, Jürgen Habermas, Ronald Dworkin, or Philip Pettit. One particularly simple and clear way to demarcate between these two fields of normative political philosophy is the one we follow in the text, i.e. to refer to two clearly distinct kinds of normative questions: the what, in the case of justice, and the who and the how, in the case of legitimacy. This does not imply that these two fields are totally disconnected. In the end, the substantive values that political philosophers use as grounds of their respective views on justice and legitimacy should, at least in part, be the same.
} 
possesses legitimacy in this sense, the decisions made by that institution or process generate certain obligations of respect on the part of those subject to those decisions. Some view such obligations of respect as instantiated by a duty to obey. ${ }^{9}$ Others believe that only just decisions generate such a duty, and that legitimacy generates the duty not to unduly interfere in the decision-making process or in the implementation and enforcement of the decisions made through it, as well as the duty not to use illegal means to try to replace the institution, reform the decision-making process, or change the decisions made. ${ }^{10}$

We assume that the best understanding of political legitimacy is a democratic one. ${ }^{11}$ This is, of course, controversial, especially at the international level, but the scope of the present article and its focus on the identification of the democratically legitimate actors of international law-making precludes providing a full argument for international democracy itself. We think, in any case, that this assumption at least captures a basic and widespread intuition about the best way to protect individual equality in public decision-making in circumstances of reasonable disagreement, ${ }^{12}$ and that the opposite of democracy, authoritarianism, can never be legitimate in this respect. That very intuition, moreover, cannot be exclusive to domestic political contexts: the reasons we have to endorse democracy domestically apply just as much to the international context. To put it simply, and as a matter of fact: 'One of the distinctive features of the global political order is that democracy is no longer confined to the nationstate. ${ }^{13}$ Of course, the rest of this article's argument is conditional upon the validity of this general assumption.

What democratic legitimacy requires specifically is just as controversial. In order to avoid entering into that discussion, we adopt a very basic and general understanding of democratic legitimacy that might be easily agreeable to most democratic theorists, at least at an abstract level. We choose to define the ideal of democratic legitimacy by reference to abstract principles, rather than by presupposing certain particular institutions or procedures. This way, we avoid the weight of historical experience and analogy with domestic democratic institutions, and can concentrate instead, and in a more innovative fashion, on assessing whether and how the requirements we draw from those abstract democratic principles might be satisfied in the current institutional conditions of international law-making.

\footnotetext{
${ }^{9}$ A John Simmons, Justification and Legitimacy: Essays on Rights and Obligations (CUP 2001); Joseph Raz, 'The Problem of Authority: Revisiting the Service Conception' (2006) 90 Minnesota LR 1003; Besson, 'The Authority of International Law' (n 7).

${ }^{10}$ Philip Pettit, On the People's Terms (CUP 2012).

${ }^{11}$ The present account is agnostic as to the existence of other competing grounds of political legitimacy and for the legitimate authority of law, including instrumental ones. We actually differ on those grounds and on the correct account of the legitimacy of international law as a whole, but agree on the primary importance of democracy for the legitimacy of international law-making and on its best understanding. For our respective accounts of the legitimacy of international law, see Besson, 'The Authority of International Law' (n 7); Samantha Besson, 'State Consent and Disagreement in International Law-Making: Dissolving the Paradox' (2016) 29 Leiden Journal of International Law 289; José Luis Martí, 'A Global Republic to Prevent Global Domination' (2010) 24 Diacrítica 31; 'Sources and the Legitimacy of International Law' (n 1).

${ }^{12}$ See Christiano, 'Democratic Legitimacy and International Institutions' (n 7).

${ }^{13}$ James Bohman, 'From Self-Legislation to Self-Determination: Democracy and the New Circumstances of Global Politics' (2016) 17 Critical Horizons 123, 123.
} 
More specifically, we presuppose that an institution is legitimate insofar as it meets four basic democratic principles: ${ }^{14}$

(i) The principle of ultimate, effective popular control, directly derived from the ideal of popular sovereignty: all people(s) affected by international law should have a say in the process of making that law. They can delegate that power to representatives. They should, however, retain ultimate, effective control over them, and, through them or by other mechanisms, over international institutions and decision-making processes, in order to make the idea of popular sovereignty possible.

(ii) The principle of political equality: those people(s) should have a fair or equal share, directly or through their representatives, in holding that ultimate power of control. That means that no individual or people should be able to impose their views unilaterally or have significantly greater political power to determine the law than others. International political power should be proportional to the population of each people.

(iii) The principle of deliberative contestability: in addition to ultimate control that might come under the form of some kind of decision power, the people(s) - or their representatives - should also (1) be able to contest in a deliberative way the laws and decisions made internationally, and (2) have the capacity to engage in deliberative interaction with each other as well as with international institutions, thus promoting public formal and informal debate. Finally, the procedures of decision and lawmaking should themselves be as deliberative as possible.

(iv) The principle of human rights' protection: individuals' human rights that guarantee their basic moral equality and enable them to exercise ultimate control should be protected in international law-making processes and institutions.

Any system of law-making will be democratically legitimate as long as it meets those four requirements. As they are scalar and hence can be met to a higher or lesser degree, any given law-making system will be more or less legitimate depending on the degree to which it meets each of those requirements. This is compatible, however, with drawing a minimal threshold of satisfaction of the requirements at which a system may be considered minimally legitimate. What are those four principles' concrete implications for the legitimate actors of international law-making?

The first democratic principle is quite clear in this respect. Given that a system of direct popular decision-making is impossible at the international level - as it has also traditionally been at the domestic level - all people(s) affected by international law necessarily have to delegate their power to representatives. This turns the question of the democratic legitimacy of international law into a question of democratic representation. Accordingly, the legitimate actors of international law-making are basically those who can represent the interests of the people(s) affected by international law. And those people(s) should

\footnotetext{
${ }^{14}$ See Martí, 'Sources and the Legitimacy of International Law' (n 1). Principles (ii) to (iv) can actually be understood as specifications of principle (i). It is important to notice that we are building our view of international democratic legitimacy on Philip Pettit's account of republican legitimacy in the domestic context, while his own view of republican international legitimacy is certainly much more deflationary. For his account of domestic legitimacy, see Pettit, On the People's Terms (n 10). For his account of international legitimacy, see Pettit, 'Legitimate International Institutions' (n 7); Philip Pettit, 'The Republican Law of Peoples: A Restatement' in Barbara Buckinx, Jonathan Trejo-Mathys and Timothy Waligore (eds), Domination and Global Political Justice: Conceptual, Historical, and Institutional Perspectives (Routledge 2015).
} 
retain the ultimate, effective control over their representatives and over the system as a whole. This means that an assessment of the legitimacy of current or potential actors of international law-making crucially depends on whether those actors can be said to have been delegated their powers by the people(s) affected by the decisions to be made, and, more importantly, on whether those people(s) enjoy access to effective mechanisms of ultimate control over them and over the decision-making system as a whole. Furthermore, for that system to be legitimate, that ultimate control needs to be exercised so as to comply with the other three requirements: political equality, deliberative contestability and respect for human rights.

In our traditional (modern) understanding of representative democracy, at least when it applies to domestic law-making, these four principles have required the existence of a parliament with fundamental powers of legislation whose members are elected democratically, a directly or indirectly elected executive, and an independent and self-standing judiciary, among other democratic institutions. Nothing like this, of course, exists at the international level. However, this does not imply that the principles of democratic legitimacy cannot be respected at all through other means. In fact, what the first principle, for instance, requires is that the people(s) affected by the decisions made in the international system can have mechanisms of ultimate control that are as effective as possible. If creating a world parliament and calling for a global election is not an available option, at least for a while, we should explore other ways by which those people(s) can exert such ultimate control, and do it in conditions of political equality, deliberative contestability, and human rights' protection. And there are many such ways, as we will see.

In sum, the main question raised by the democratic legitimacy of international lawmaking is the following: who can adequately represent the people(s) interests, views, and claims, allowing those people(s) to retain ultimate, effective control, exerted in conditions of political equality, deliberative contestability, and protection of human rights? ${ }^{15}$ Let us now assess the two main answers given to this question, first by the Statist Model and then by the Dualist Model.

\section{The Statist Model}

The most obvious answer to the democratic legitimacy challenge in international law is that the legitimate actors of international law-making, qua legitimate representatives of the people(s), are their states.

This means basically their state governments to the extent that they have the right, under the domestic constitutional order of most states and as confirmed by the rules on default full powers to conclude international agreements under the international law of treaties (arts 7(2), 8 and 46 of the Vienna Convention on the Law of Treaties [VCLT]), to bind their states in the latter's external relations, and hence to speak for the people in those states on the international plane. By extension, state-based IOs are also considered legitimate actors of international law-making, to the extent that they

\footnotetext{
${ }^{15}$ For reasons of space, we have decided to focus our argument in the remainder of this article on the first three democratic principles, and leave human rights aside. To some extent, however, respect for human rights is subsumed in respect for political equality, and is discussed among the inherent limits to the PSC in sections 3 and 4.
} 
represent states and are delegated some of their powers, thereby making for a complex two-tier form of representation. State-like IOs, like the EU, actually represent people(s) both directly through EU institutions and indirectly through states (art 10(1) and (2) of the Treaty of the European Union [TEU]).

The fact that these 'statist' (i.e. state and state-based/state-like) actors continue to play a central part in international law-making is uncontroversial. And so is, to a large extent, the corresponding Statist Model of the legitimate actors of international law-making, at least from a descriptive point of view. But how should we evaluate this fact from the point of view of democratic legitimacy?

States are valuable from a domestic and international perspective, both generally and from a democratic point of view. Generally, first of all, they pursue the most ambitious aims political communities can pursue, which are public justice and the common good. ${ }^{16}$ Achieving justice and the common good have since then also become universal aims entrenched in international law norms and whose implementation is primarily to be domestic and state-driven. As a matter of fact, states have been the ground on which the international legal system has flourished in the last couple of centuries. Even the biggest international institutional innovation of the twentieth century, i.e. the creation of hundreds of IOs, has been driven through the intervention of states, which have constituted them to coordinate their actions, delegated certain powers to them and held them accountable.

From a democratic perspective, secondly, states gather a combination of constitutive elements that best match some of the factual conditions for the justification of democracy, ${ }^{17}$ and in particular a territory, a stable population whose members share an effective connection to one another and hence equal and interdependent stakes, and the capacity for effective government. Those constitutive features of the state are actually protected through international law principles pertaining to the state structure, such as territorial integrity, nationality, jurisdiction and sovereignty. There are, accordingly, at least two reasons for considering states as the democratically legitimate actors of international law-making, at this relatively early stage in the development of international institutions: 'one, states are still by far the most effective systems for making power accountable to persons', ${ }^{18}$ and for doing so in the greatest respect possible of political equality, deliberative contestability and human rights. Second, 'these states are in a position to represent their members to the larger community. ${ }^{19}$ Because of the domestic development of democratic accountability, states are able to make not only their own laws responsive to the interests of their people, but also their contributions to international decision-making.

The development of democratic states over the past century or so is a crucial historical achievement, and one that has actually since then become entrenched by the international customary law principles of individual equality and democracy. The development of international law should therefore draw in priority on domestic democratic institutions in order to secure the democratic legitimacy of international law.

\footnotetext{
${ }^{16}$ Thomas Christiano, 'Replies to David Alvarez, David Lefkowitz, and Michael Blake' (2016) 4 Law, Ethics and Philosophy 221, 222.

${ }^{17}$ Christiano, 'Democratic Legitimacy and International Institutions' (n 7) 121-22.

${ }^{18}$ Christiano, 'Replies' (n 16) 223.

${ }^{19}$ ibid.
} 
The main instrument, albeit not the only one, for the participation of states in international law-making, and hence for the representation of their people in that process, has been the PSC. Even though it has changed in nature over time, state consent still plays an important role in international law-making. ${ }^{20}$ After all, international legal obligations are never imposed on states without their (unanimous) consent. This is not only an observable reality, but also one that we would like to argue is democratically justified. $^{21}$

Starting with the descriptive discussion, first of all, it is important to emphasise that state consent has taken a variety of forms in the sources of international law. As of late, however, it has become common for international lawyers to describe or, at least, to predict the erosion of state consent in international law-making. ${ }^{22}$

Importantly, the changes usually identified in the international law-making process are mostly located at the periphery of or even outside the sources of international law. The examples most mentioned indeed are the rise of 'soft law' and the prevailing role of unilateral decisions by powerful states. ${ }^{23}$ Although there are clearly new non-(state-)consensual means of international cooperation at play, neither of them are (yet) regarded as sources of international law stricto sensu. So, if there is a threat to the role of state consent in international law-making, it is external rather than internal to international law, whatever that means for the current state and role of international law. More importantly, the latter remains (state-)consent-based even when private or civil society actors are associated with the international law-making process. This is the case of the most important sources of international law, i.e. treaties and customary international law. The nonexclusivity of state participation is no evidence of the erosion of state consent. Quite the contrary, as we will argue in section 7.

Amidst the evidence put forward to undermine the claim that international law imposes no obligation without state consent and that the sources of international law are no longer consent-based, one usually find three elements: the existence of jus cogens norms states should not derogate from even when they disagree with them; the legislative role of IOs whose law binds states even against their consent; and, finally, the fact that custom binds every new state qua state and independently of its consent.

Starting with the last argument and going up the list, it is not surprising that customary international law may prima facie seem to bind some states without or even against their consent: its formation depends on a general practice only, but its authority extends to all states. Importantly, however, that authority only extends to a state provided it has not objected, expressly and persistently, to the emerging consensus. Each state may therefore dissent, and, so doing, withdraw the consent it was otherwise giving tacitly. ${ }^{24}$ As a result, customary international law-making combines tacit consent in the converging practice of states and explicit dissent in their possibility to object to that practice through a persistent objection. To that extent, like international treaties, customary international law cannot impose obligations on states without their consent. This is also true of new states that

\footnotetext{
${ }^{20}$ Besson, 'State Consent and Disagreement in International Law-Making' (n 11) 303-304.

${ }^{21}$ ibid; see also Samantha Besson, 'Law Beyond the State: A Reply to Liam Murphy' (2017) 28 EJIL 233.

${ }^{22}$ Christian Tomuschat, 'Obligations Arising for States Without or Against Their Will' (1993) 241 Collected Courses of The Hague Academy of International Law 195; Nico Krisch, 'The Decay of Consent: International Law in the Age of Global Public Goods' (2014) 108 AJIL 1.

${ }^{23}$ Pauwelyn, Wessel and Wouters (n 3).

${ }^{24}$ Prosper Weil, 'Towards Relative Normativity in International Law' (1983) 77 AJIL 413, 433-34.
} 
may oppose a persistent objection. The self-determination of newly created states was actually one of the justifications for the introduction of the possibility to waive a persistent objection in the 1960s.

In reply to the critique pertaining to the legislative role of IOs, second, one should stress that the authority of their internal law still relies indirectly on their constitutive treaties, and hence on state consent or, at least, on states' subsequent converging practice. ${ }^{25}$ The same may be said about the development of international adjudication by international courts constituted by international treaties or within the institutional structure of IOs.

Regarding the first objection, i.e. the emergence of jus cogens norms, one may stress that what characterises jus cogens norms is their normative stringency, but not their sources. Of course, the latter have to be such that those norms' stringency can be absolute. However, practice shows that jus cogens norms arise, when they do, from treaties as much as from customary international law. This is also what Article 53 VCLT indicates when it states that a jus cogens norm is a norm 'accepted and recognised by the international community of states as a whole' as being peremptory through the sources of international law. As a result, and to some extent, a jus cogens norm cannot arise without the consent of the states it binds.

Of course, jus cogens norms, once they have arisen, may in some cases pose limits to state consent. In order to fully grasp the justification for those inherent limits to state consent, secondly, it is important to turn to the normative case for state consent's role in the democratic justification of obligations under international law.

Just as individuals' unanimous consent cannot be a requirement of the justification of the authority of domestic law, ${ }^{26}$ state consent, understood as unanimous acceptance, cannot be a requirement of the legitimate authority of international law. Its role goes beyond enhancing general respect and compliance with international law, however. ${ }^{27}$ Even if state consent does not amount to an actual requirement of the legitimacy of international law, its central role in contemporary international law may be justified democratically, and even more so in the circumstances of widespread and persistent reasonable disagreement that characterise international law-making. ${ }^{28}$

At first, of course, such an argument for democratic state consent may sound paradoxical. Indeed, domestically, the role of consent has long been disparaged from a democratic perspective precisely because of reasonable disagreement. ${ }^{29}$ Actually, the equality-based justification of democracy accounts for majority-voting instead of unanimity, thus making consent even less relevant procedurally in a democracy. Importantly, however, democratic considerations in international law should not be conflated with domestic ones. Indeed, states, qua democratic representatives of their people, cannot be treated as equal individual members of an international democratic polity in the same way as individuals are equal members of a domestic democracy.

\footnotetext{
${ }^{25}$ Jan Klabbers, 'Law-making and Constitutionalism' in Jan Klabbers, Anne Peters and Geir Ulfstein, The Constitutionalization of International Law (OUP 2011) 100 and 114.

${ }^{26}$ Joseph Raz, The Morality of Freedom (OUP 1986) 88ff.

${ }^{27}$ Liam Murphy, What Makes Law: An Introduction to the Philosophy of Law (CUP 2014); Liam Murphy, 'Law Beyond the State: Some Philosophical Questions' (2017) 28 EJIL 203.

${ }^{28}$ Besson, 'State Consent and Disagreement in International Law-Making' (n 11) 305-12; Thomas Christiano, 'Climate Change and State Consent' in Jeremy Moss (ed), Climate Change and Justice (CUP 2015).

${ }^{29}$ Christiano, 'Climate Change and State Consent' (n 28).
} 
The importance of democratic legitimacy domestically implies indeed that we should try to find a way to respect domestic democracy in the way we make international law, and especially the political equality of the people of democratic states. After all, to quote Christiano again, states 'are still by far the most effective systems for making power accountable to persons in the international system' ${ }^{30}$ It should be clear therefore that the way to link international law-making processes to domestic democratic legitimacy is to respect the equality of each democratic state qua (state's)people. The means to protect the equality of states('peoples) qua public equality is to consider their consent as a requirement in international law-making rather than rely on a majority of state votes. The requirement of equal consent of states enables small and weak states to resist the domination and the hegemony of large and powerful states or coalition of states $^{31}$ - albeit not necessarily completely so, as we will see in section 4.2. In turn, states' equal consent protects the individual members of those states' right to an equal voice in the collective decision-making process they are participating in through their states as representatives. ${ }^{32}$

Of course, there are many ways of accounting for the democratic role of state consent in an account of the democratic legitimacy of international law. For some democratic theorists, the way in which state consent ties in is merely as a democratic exception to the legitimate authority of international law that should be justified on other grounds. ${ }^{33}$ It is precisely because reasonable disagreement among states is widespread and persistent in international law-making, on the one hand, and because of the centrality of democratic states in making international power accountable to their people, on the other, that democratic state consent should work as an exception to the otherwise legitimate authority of international law. For others, however, albeit for the same reasons, democratic state consent should work as an actual ground for the latter's democratic authority.

Either way, while democratic state consent should be considered an important dimension of the democratic legitimacy of international law, there are inherent limits to it. ${ }^{34}$ The first set of limits pertains to its democratic justification and the protection of the democratic states' peoples. Because the justification of the opposability of state consent to the legitimate authority of international law is democratic, this makes for inherent democratic limits to it. ${ }^{35}$ Those limits amount, as we will discuss in sections 4 and 7.2, to the protection of the basic conditions of democracy, i.e. political equality and human rights, and correspond, at least, to the jus cogens limits to (democratic) state consent mentioned before. A second set of limits inherent to democratic state consent have to do with consent itself. There are at least three, as we will discuss in sections 4 and 7.2: the free and unconstrained nature of state consent; its fairness and egalitarian features; and its informed und unbiased nature. ${ }^{36}$

\footnotetext{
${ }^{30}$ Christiano, 'Replies' (n 16) 223.

${ }^{31}$ Klabbers, 'Law-making and Constitutionalism' (n 25) 114.

${ }^{32}$ Christiano, 'Climate Change and State Consent' (n 28).

${ }^{33}$ Besson, 'The Authority of International Law' ( 7 ); 'State Consent and Disagreement in International Law-Making' (n 11).

${ }^{34}$ Besson, 'State Consent and Disagreement in International Law-Making' ( $\left.\mathrm{n} 11\right)$.

${ }^{35}$ ibid; Christiano, 'Democratic Legitimacy and International Institutions' (n 7).

${ }^{36}$ Besson, 'State Consent and Disagreement in International Law-Making' (n 11); Christiano, 'Climate Change and State Consent' (n 28).
} 


\section{Shortcomings of the Statist Model}

Even though the PSC has been, and still is very important for the democratic legitimacy of international law-making, it also suffers from serious shortcomings from a democratic perspective.

There are, we submit, at least nine sources of concern with it, connected to three of the principles of democratic legitimacy introduced before: ${ }^{37}$ lack of representativeness (4.1), democratic inequality (4.2), and lack of deliberative contestability (4.3).

\subsection{Lack of representativeness}

There are at least two main sources of democratic deficit of the PSC with respect to the democratic requirement of representativeness: the existence of non-democratic states, and the limited accountability of state governments.

First, the existence of non-democratic states. State consent only protects democratic selfdetermination provided the state itself is democratic. To that extent, the PSC leaves the citizens of non-democratic states unrepresented.

The problem is that, currently, at least one half of the states in the world are non-democratic, according to very modest standards of democracy (e.g. those of the Democracy Index). Non-democratic states may claim to represent their people, but their claim is unwarranted for the latter cannot exercise ultimate, effective control over their state government's actions. Contrary to what is usually presupposed in international law theory, therefore, and to go back to the Chinese citizen's example, non-democratic governments like the government of China do not truly represent their citizens despite their claim to do so. Consequently, the Chinese people and the people of non-democratic states are not represented in the system of international law-making, and this makes such a system that is based on state consent deficient from a democratic point of view. ${ }^{38}$

Second, the limited accountability of state governments. State consent is blind to the actual domestic democratic accountability of state governments. To that extent, being a democratic state in the formal sense does not guarantee that the government is effectively representing their citizens, especially on issues such as international affairs.

The problem is that, since the international actions of state governments' officials are not necessarily submitted to ultimate, effective control of the people under domestic law, whether that control occurs indirectly through parliament (e.g. parliamentary approval of treaties) or directly through the people itself (e.g. popular referendum on treaties), it is difficult to say that the government of a democratic state always ensures the international representation of that state's people.

Of course, governments are elected, whether directly or indirectly, by the people and international law issues may arise in that context. However, even in democratic states, like Spain, international affairs are not usually very salient in the internal agenda of

\footnotetext{
${ }^{37}$ Besson, 'Law Beyond the State' (n 21); Martí, 'Sources and the Legitimacy of International Law' (n 1). Some of those democratic shortcomings apply to state representation domestically as well, while others are specific to their participation in international decision-making or, at least, are magnified in the international context. What this means, of course, is that fixing them on the international plane may have consequences on the domestic level, and vice versa.

${ }^{38}$ Christiano, 'Democratic Legitimacy and International Institutions' (n 7); 'Democracy' (n 6); Buchanan and Keohane (n 7); Robert Dahl, 'Can International Organizations be Democratic? A Skeptical View' in lan Shapiro and Casiano Hacker-Cordón (eds), Democracy's Edges (CUP 1999).
} 
public debate. As a result, people, as in the example of the Spanish citizen worried about climate change, largely ignore what their governments are doing on the international plane. ${ }^{39}$ What is worse, even when they are duly informed, they lack adequate, effective methods to make their governments act in a certain direction internationally. It is quite likely, for instance, that a majority of Spanish citizens would prefer their government to have a stronger and more decisive international policy regarding climate change, but they do not have the means to impose those views on their government. The reason is that elections are always decided on the basis of a vast and largely heterogeneous agenda, where international affairs have to compete with too many other important issues. Once the government is elected, as a result, it almost enjoys a blank check on the international front. In other words, important as elections may be for democratic representation, they have proven to be a very imperfect mechanism of ultimate, effective popular control.

Domestic democracy, we might conclude, has not been well designed so far to appropriately organise accountability on international issues, partly because such issues have never been as crucial for our lives as they are now. As a result, the governments of most existing democracies are very imperfect representatives of their people's interests, views, and claims in international affairs. Accordingly, the Spanish citizen in our example may well be justified in believing that the legitimacy of the Spanish government as an actor of international law-making is, for that reason, undermined or diminished.

\subsection{Political inequality}

Even if the governments of all states in the world were democratic and internally accountable to their people, as the principle of ultimate, effective popular control requires, there are at least four further sources of democratic deficit of the PSC that need to be addressed, this time with respect to the democratic principle of political equality: the disproportions in demography, the imbalance of informal power among states, the problem of permanent minorities, and the unequal distribution of views.

First, disproportions in demography. State consent does not pay sufficient attention to individual equality by not being proportional to the demographic composition of states. To that extent, the PSC treats the citizens of those different states unequally.

The problem is that, if all states have the same privilege or right to use or oppose state consent, then states with a very small population hold, proportionally, much more power than those with larger ones, and this violates the principle of political equality. This is an implication of the lack of transitivity between individual and state equality. In effect, the traditional interpretation of the SM has tended to equalise, at least formally, the power of all states, particularly through the PSC. And the rule of one state, one vote produces tremendous political inequalities. What the principle of political equality would require indeed is for each state to hold an amount of international power that is proportional to its population. In the case of the Chinese citizen, it is obvious that her political weight in the international system is much lower than that of any other non-Chinese citizen in the world. To that extent, the Spanish citizen in our example,

\footnotetext{
${ }^{39}$ Buchanan and Keohane (n 7); Dahl (n 38).
} 
who lives in a less populated state, is treated more equally by the international lawmaking process.

Second, the imbalance of informal power among states. State consent does not pay sufficient attention to individual equality by not being sensitive to the power imbalance among states. To that extent, the PSC treats the citizens of those different states unequally.

The problem is that, in international relations, more powerful states - in economic, military, or cultural terms - are generally able to impose informally their views and interests onto less powerful ones. ${ }^{40}$ Thus, the PSC cannot grant every state's people an equal share in the international law-making process, unless one finds a way of distributing international power more equally across states, making it only proportional to the states' population. The United States has far more power than China despite having four times less population. Thus, the Chinese citizen in our example would not be treated as an equal compared to an American citizen even if the government of her country were democratic and internally effectively accountable.

Third, the existence of permanent minorities. Even in an international system like the existing one in which state consent is not only used as a veto power, there is a permanent risk of producing entrenched, persistent or permanent minorities. To that extent, the PSC may treat the citizens of states in the minority unequally by practically excluding them from international law-making, even if their governments are democratic and effectively accountable to their people, and even if their power is in principle proportional to their population.

The problem is that, when state consent is put into practice through a mechanism of majority rule, the world can, and normally does, divide into regional or transregional coalitions or blocs of interests. There is a risk, as a result, that some majorities and minorities of states freeze over time and over certain issues, preventing the taking turns on a broad range of issues that is required for democratic representation in law-making. ${ }^{41}$ What this implies is that some people(s) will permanently be on the losing side in international decision-making processes because their states and representatives are practically excluded from international law-making, thus violating the principle of political equality. In the Chinese and Spanish examples, this could be illustrated by the Asian and European trade coalitions, but also by the respective environmental stakes and policies of those two blocs of states.

Fourth, the unequal distribution of views. State consent does not reflect adequately all views to the extent that those views are not necessarily distributed equally among states. To that extent, the PSC may treat the citizens of those different states, whether democratic or not, unequally.

This is a problem that emerges in any two-tier decision-making system, domestic or international, like the one defended by the SM. Imagine a world divided in 10 countries of 10 million people each. The hundred million individuals of such a world divide into two groups over the issue of environmental protection - for and against - but their views are unequally distributed over the issue. In four countries, 100 per cent of their citizens are in favour of environmental protection. In the other six, only 45 per cent of them are, while the other 55 per cent are against. In a statist democratic order where

\footnotetext{
${ }^{40}$ Christiano, 'Democratic Legitimacy and International Institutions' (n 7) 132-33; 'Climate Change and State Consent' (n 28).

${ }^{41}$ Christiano, 'Democratic Legitimacy and International Institutions' (n 7) 133-34.
} 
governments are truly representative and internally accountable, a majority of 6 out of the 10 state governments should push international law-making against environmental protection, since the majority of their respective citizens are against it. And this despite the fact that 67 million individuals (more than two thirds of the hundred million) are actually in favour of environmental protection. This is an unjustifiable breach of political equality.

\subsection{Lack of deliberative contestability}

There are at least three further sources of democratic deficit of the PSC, this time with respect to the principle of deliberative contestability: consent as veto, lack of expertise, and the neglect of collective interests.

First, consent as veto rights. Despite growing exceptions, state consent still is largely veto-centred in practice and does not, as a result, usually encourage sufficient deliberation among democratic states. To that extent, the PSC does not grant citizens a sufficient capacity to engage in deliberative interaction with each other within states, as well as among themselves and with international institutions.

The problem is that, because state consent is mostly articulated through a mechanism of veto power, it often undermines the possibility of democratic deliberation among states. There are indeed only very few incentives to deliberate in such international decisionmaking processes given the costs in terms of what the ultimate decision would be: a state could simply decide to veto a decision from the very beginning and without giving any reasons. What veto power mechanisms produce, in other words, is the prevalence of bargaining, which is conceptually different from, and sometimes even opposed to, deliberation. If one or a few states regularly veto certain decisions, this gives other states an incentive to offer a price to - or, conversely, to use threats against - those vetoing countries, in order to obtain their consent. This, in turn, gives incentives to potential vetoing states to enter a bargaining game instead of trying to exchange reasons for and against the potential decisions to be made. Imagine Spain has a veto power over the international climate change policy. Even if the Spanish government represented adequately its people's demands for firmer and more effective steps in the area, its threat to use the veto authorised by the PSC or its use by other states may not induce deliberation with other states on how best to tackle climate change.

Second, the lack of expertise. For the reasons just mentioned, state consent is largely procedural in practice, and does not guarantee that sufficient information flows into the deliberation among democratic states for the latter to be successful. To that extent, the PSC does not secure citizens a sufficient capacity to engage in deliberative interaction with each other within states, as well as among themselves and with international institutions.

The problem is that global issues are more and more difficult to understand and address, and often require expertise to start the deliberation, but also, conversely, deliberation to take place in order to enhance the epistemic abilities of those deciding over them. State consent mostly works as a procedural means of decision-making, however, and provides very little chance for epistemic input into the international deliberative process. ${ }^{42} \mathrm{To}$ go back to the Spanish citizen concerned about climate change, it is uncertain that he can

${ }^{42}$ Christiano, 'Democracy' (n 6). 
expect his government, and that of other states, to secure the expertise needed for deliberation to even take place at both the domestic and international level on those issues and hence for the epistemic virtues of deliberation to unfold. Instead, international decisions on those issues are likely to be taken without deliberation.

Third, the neglect of collective interests. State consent may be based on state individual or partial interests only and does not necessarily secure consideration of other global collective or general interests necessary for a complete deliberation process. To that extent, the PSC does not secure citizens a sufficient capacity to engage in deliberative interaction with each other within states, as well as among themselves and with international institutions.

The problem is that states have individual interests, i.e. the self-regarding or partial interests held collectively by their population, that they promote internationally (e.g. economic interests), but may not sufficiently promote the global collective or general interests that are also held collectively by their population (e.g. environmental interests). ${ }^{43}$ The PSC does not exclude that they could, ${ }^{44}$ but does not per se guarantee that state governments, when they express or deny their state consent, do not do so exclusively on grounds of individual state interests. In other words, it cannot ensure that state governments rely on grounds of global collective interests when those apply. ${ }^{45}$ This comes out very clearly in the example of the Spanish and Chinese citizens given how the two states defend their respective positions internationally, and especially on the international environmental law-making front, thereby excluding any fruitful deliberation on those issues.

In conclusion, the contribution that the PSC can make to legitimate international lawmaking is conditional upon its success in overcoming those important democratic shortcomings, and the SM should be refined to provide such an account (see section 7.2.).

\section{The Dualist Model}

Motivated by the desire to overcome the democratic shortcomings of the SM, some authors have argued that states, and state-based or state-like entities like IOs, should not be the only legitimate actors of international law-making. They should rather be complemented by another kind of actors: private actors ${ }^{46}$ coming from civil society, most of which have already started to play an increasingly significant role in international decision and law-making fora. ${ }^{47}$

\footnotetext{
${ }^{43}$ Samantha Besson, 'Community Interests in International Law: Whose Interests are They and How does One Identify Them?' in Eyal Benvenisti and Georg Nolte (eds), Community Obligations in Contemporary International Law (CUP 2018).

${ }^{46}$ We rely here on the intuitive divide between public and private actors in international law-making as referring to the divide between states and state-like/state-based actors like IOs, on the one hand, and individuals and groups of individuals acting in their own capacity, on the other. The negative identification of 'private' actors by reference to 'public' ones, and their corresponding qualification as 'non-state' actors should not be read as an endorsement of the alleged 'original', 'plenary' and 'objective' legal personality of states only under international law and the corresponding negative definition of the rights and duties of other subjects to international law wrongly considered as 'derived', 'partial' and 'subjective'. Rather, if the 'private' is defined by reference to 'public' on this account, it is because the 'public' relies on a delegation of power from the sovereign people to collective agents, and this distinguishes collective 'public' actors acting upon this delegation, like statist actors, from mere individual or collective 'private' ones acting in their own capacity, like civil society actors.

${ }^{47}$ Jürgen Habermas, 'European Citizens and European Peoples: The Problem of Transnationalizing Democracy' in The Lure of Technocracy (Ciaran Cronin tr, Polity Press 2015); Jürgen Habermas, 'Kant's Idea of Perpetual Peace: At Two Hundred Years' Historical Remove' in Inclusion of the Other: Studies in Political Theory (MIT Press 1998); Colás (n 2); Kaldor (n 2);
} 
Interestingly, this scholarly move towards opening up the circle of international lawmaking actors to civil society actors matches important developments in the practice of international law-making. ${ }^{48}$ Two well-known examples, among many others, are the negotiation of the Convention on the Prohibition of the Use, Stockpiling, Production and Transfer of Anti-Personnel Mines and on their Destruction in 1997, and of the Rome Statute for the International Criminal Court (ICC) in 1998. If the latter constitute examples of the decisive role of NGOs to the success of international law-making, many argue that NGOs were crucial to stop the Multilateral Agreement on Investment in 1998, which would reveal that they can also have the political power to block important international law-making initiatives. To these three examples of international law-making proper - two positive and one negative - we can add many others in which civil society plays an important role in the interpretation and enforcement of international law, and therefore in the further derived international law-making processes that occur in that context. ${ }^{49}$ A paradigmatic example of the latter is the international law-making system created by the Montreal Protocol on the Ozone Layer to the Vienna Convention in 1989, especially through the important work done by the Technology and Economic Assessment Panel (TEAP) and the Technical Options Committees (TOCs). ${ }^{50}$

What all these examples illustrate is that civil society actors are arising as important actors in practice, not only in the context of the implementation and enforcement of international law or of the accountability of international institutions, but also in the process of international law-making itself. What they all have in common, however, is that when civil society actors are included in international law-making, it is on top of and together with statist actors.

Importantly, none of the promoters of the DM have argued for the exclusion of states or state-based IOs from the international law-making process. What they suggest instead is some form of complementarity between these two types of actors. They advocate a combination of public and private actors of international law-making, thus expanding the traditional SM which is usually monist about the nature of the actors of international law-making. This is why the model they defend may be referred to as the Dualist Model.

The attractiveness of the DM from the perspective of democratic theory is obvious. The statist model is insufficient to secure the democratic legitimacy of international law

Keane, Global Civil Society? (n 2); Slaughter (n 2); Anne Peters, 'Global Constitutionalism Revisited' (2005) 11 International Legal Theory 39; Anne Peters, 'Dual Democracy' in Jan Klabbers, Anne Peters and Geir Ulfstein (eds), The Constitutionalization of International Law (OUP 2011); Anne Peters, 'Are We Moving Towards Constitutionalization of the World Community?' in Antonio Cassese (ed), Realizing Utopia: The Future of International Law (OUP 2012); Anne Peters, 'Global Constitutionalism' in Michael Gibbons (ed), The Encyclopedia of Political Thought (Wiley Blackwell 2015); John Dryzek, Deliberative Global Politics (Polity Press 2006); John Dryzek, 'Global Deliberative Democracy' in Jean-Frédéric Morin and Amandine Orsini (eds), Essential Concepts of Global Environmental Governance (Routledge 2014); James Bohman, Democracy Across Borders (MIT Press 2007); James Bohman, 'Democratising the Global Order: From Communicative Freedom to Communicative Power' (2010) 36 Review of International Studies 431, 431; Bohman, 'From Self-Legislation to Self-Determination' (n 13); Buchanan and Keohane (n 7); Gráinne de Búrca, Robert Keohane and Charles Sabel, 'New Modes of Pluralist Global Governance' (2013) 45 New York U Journal of International Law and Politics 723; Gráinne de Búrca, Robert Keohane and Charles Sabel, 'Global Experimentalist Governance' (2014) 44 BJPS 477; Jessica Green, Rethinking Private Authority: Agents and Entrepreneurs in Global Environmental Governance (Princeton UP 2014); Jonathan Kuyper, 'Global Democratization and International Regime Complexity' (2014) 20 EJIR 620; Jonathan Kuyper, 'Systemic Representation: Democracy, Deliberation, and Nonelectoral Representatives' (2016) 110 APSR 308; Mattias Kumm, 'Constituent Power, Cosmopolitan Constitutionalism and Post-Positivist Law' (2016) 14 IJCL 697.

${ }^{48}$ Alan Boyle and Christine Chinkin, The Making of International Law (OUP 2007) ch 2.

${ }^{49}$ For examples, see de Búrca, Keohane and Sabel, 'New Modes of Pluralist Global Governance' (n 47).

${ }^{50}$ De Búrca, Keohane and Sabel, 'Global Experimentalist Governance' (n 47); Green, Rethinking Private Authority (n 47); Hayley Stevenson and John Dryzek, Democratizing Global Climate Governance (CUP 2014). 
because, as we saw in the last section, it leaves an important number of people unrepresented or inadequately represented, does not secure political equality, and does not sufficiently promote the deliberative contestability of the system. Taking all this into account, it is easy to see why allowing the participation of civil society actors in international lawmaking processes could help alleviating some of those democratic deficits. NGOs, for instance, may give voice to unrepresented people or to those insufficiently represented. They can also strengthen the visibility of those who have been treated unequally, and empower those who have become persistent minorities. Finally, to the extent that many of them do not only have a domestic basis, they may help to protect the general interests of the global public against national biases or partial interests. Accordingly, their participation can bring positive effects for the deliberative contestability of the whole system: NGOs can press, for instance, international institutions to become more transparent and to provide good reasons and justifications for their decisions. To quote Peters, the trend that integrates the transnational civil society into the fabric of international law [...] arguably promotes the constitutional principles of broad deliberation, transparency and public accountability. ${ }^{51}$

True, in the domestic context, democratic theory has long considered civil society organisations as crucial for the quality of democracy. ${ }^{52}$ For some authors, the non-institutional public sphere in which such civil society actors operate is almost as important as the institutional public sphere for the health of a vibrant and fully legitimate deliberative democracy. ${ }^{53}$ It makes the latter not only more participatory by enabling different kinds of contestation, and more inclusive by opening it to new actors, but also, and crucially, more deliberative by making public debate more plural. What is crucial is to see that these organisations may also contribute more directly to institutional decision-making, and not only to informal public deliberation, and thereby may make the former more deliberative and democratic. Of course, it would be exaggerated to consider that all democratic theorists are happy with opening up domestic law-making processes to civil society actors. However, the participation and significant contribution of civil society to the good functioning of domestic democratic institutions is mostly welcomed and defended as necessary to strengthen the legitimacy of the democratic system. ${ }^{54}$ If that is the case at the domestic level, where representative institutions such as parliaments and elected executives are well established and consolidated, then it should not come as a surprise that it should also be the case on the international plane, where the SM suffers from all the democratic shortcomings reviewed in the last section.

\footnotetext{
${ }^{51}$ Peters, 'Global Constitutionalism Revisited' (n 47) 55. See also Bohman, 'Democratising the Global Order' (n 47); 'From Self-Legislation to Self-Determination' (n 13); de Búrca, Keohane and Sabel, 'New Modes of Pluralist Global Governance' (n 47); 'Global Experimentalist Governance' (n 47).

${ }^{52}$ The extensive literature on civil society in democratic theory originates from one of Habermas' early and most influential books: The Structural Transformation of the Public Sphere (MIT Press 1989), published in German in 1962. See also Jürgen Habermas, Between Facts and Norms (William Rehg tr, MIT Press 1996); Jürgen Habermas, The Postnational Constellation (Max Pensky tr, MIT Press 2001); Robert Putnam, Making Democracy Work (Princeton UP 1993); Joshua Cohen and Andrew Arato, Civil Society and Political Theory (MIT Press 1992); Joshua Cohen and Joel Rogers, 'Secondary Associations and Democratic Governance' (1992) 20 Politics and Society 393; Joshua Cohen and Joel Rogers, 'Associations and Democracy' (1993) 10 Social Philosophy and Policy 282; Jeffrey Alexander, The Civil Sphere (OUP 2006).

${ }^{53}$ Habermas, Between Facts and Norms (n 52); The Postnational Constellation (n 52).

${ }^{54}$ For a recent, powerful defence, see Beth S Noveck, Smart Citizens, Smarter State: The Technologies of Expertise and the Future of Government (Harvard UP 2015).
} 
In light of this discussion, different versions of the DM have been defended. One prominent (negative) defence of a mode of global governance that is open to, and even based on, the participation of non-state actors has been proposed by de Búrca, Keohane and Sabel in their global experimentalist governance model (GXG). They see the participatory or deliberative and inclusion benefits of the GXG or, more generally, of 'democratic experimentalism' in the alternative they constitute to the PSC and the primarily statebased sources of international law. ${ }^{55}$ According to them, the GXG opens the agenda when it is closed, includes actors that would not be represented otherwise in statecentred international law-making, fosters and sometimes creates global public deliberation, and triggers contestation when there is none. ${ }^{56}$

Another, and more positive, defence of the significant role that a global civil society should play for the democratic legitimacy of international law-making has been proposed by Bohman. His account is grounded on Habermasian ideas about communicative power and the public sphere, as well as on republican concerns about freedom as non-domination. According to him, the emergence of a global public sphere or, more exactly, of a juxtaposition of several global public spheres, dynamised by NGOs and other civil society actors, contributes to incorporating a wider plurality of views, and thus promotes communicative freedom, enriches global deliberation, and helps creating a sense of global citizenship. ${ }^{57}$ More recently, and influenced by democratic experimentalism, Bohman has also advocated the creation of complex units of global decision-making that could enable citizens and global civil society actors to interact with states in open and deliberative ways. This could lead to a shift away, he argues, from the old democratic paradigm of self-legislation to a new idea of self-determination based on the republican principle of freedom as non-domination. ${ }^{58} \mathrm{He}$ sees civil society as a precondition of the democratisation of the international order. ${ }^{59}$

Whereas the SM operates on the basis of the PSC, the DM relies arguably on a different, albeit not entirely opposed, principle: the Principle of Civil Society Participation (PCSP). That principle makes it possible for private, civil society actors to play a non-trivial role in processes of international law-making, and therefore to become legitimate actors of international law-making. Precisely because it is dualist, the DM does not preclude the concurrent participation of states and other public entities in those processes. However, to the extent that actors other than states may also have a say and an important role, it is evident that the PSC should be correspondingly weakened or reconceived in the context of the DM. The more legitimate power this new kind of actors attracts or accumulates, the lesser the power of public actors of international law such as states and statebased IOs.

Even conceived in this complementary way to the SM, the DM is not free from important shortcomings. Many of them have actually been identified by its own proponents. Some of them are conceptual and derive from a lack of concrete definition, and we will

\footnotetext{
${ }^{55}$ De Búrca, Keohane and Sabel, 'Global Experimentalist Governance' (n 47) 483-84.

${ }^{56}$ De Búrca, Keohane and Sabel, 'New Modes of Pluralist Global Governance' ( $n$ 47); 'Global Experimentalist Governance' (n 47). See also Stevenson and Dryzek, Democratizing Global Climate Governance (n 50).

${ }^{57}$ Bohman, 'Democratising the Global Order' (n 47).

${ }^{58}$ Bohman, 'From Self-Legislation to Self-Determination' (n 13).

${ }^{59}$ Bohman, 'Democratising the Global Order' (n 47) 446.
} 
discuss them now. Others, like those we will discuss in the next section, are specifically democratic deficits.

One of the first conceptual problems of the DM is a persistent lack of definition about what kind of specific actors can be described as civil society actors, at least for the purpose of democratic theory. Of course, there are paradigmatic cases that emerge across the literature, like certain NGOs that intervene disinterestedly in defence of what they take to be the general interest. However, the contours of that concept remain unclear. As Peters concedes, 'the multiple actors which contribute to the generation of hard and (more often) soft transnational norms are not per se legitimate law-makers' ${ }^{60}$

So, should we include, among these civil society actors, other organisations like trade unions, churches, universities, secondary associations (such as networks of national civil associations) etc? They are certainly part of the civil society, and their motivations might be similar to those of the NGOs. Should we then also include corporations and other economic agents, which as a matter of fact undoubtedly play an increasingly important role in international law-making? It is one thing to let public-interest NGOs have a say in law-making, but quite another to welcome all sorts of lobbyists into international law-making processes and thus to let 'groups with hidden agendas, hoping to capitalise on processes that give them the ability to shape agendas or to exercise vetoes at crucial points' to capture such processes. ${ }^{61}$ As a matter of fact, there is at least one trend in the civil society literature that has tried to exclude economic actors from its scope, differentiating them from the so-called third sector exemplified mostly by NGOs. $^{62}$

There is no clear way, however, to distinguish, in general and ex ante, between 'good' and 'bad' members of civil society, between 'democratic' and 'non-democratic' ones, or between those concerned with general or collective interests and those who are merely motivated by personal or partial agendas. The fact that some actors may be referred to as 'for-profit' and others as 'non-profit' is not enough. Not only are not all non-profit organisations necessarily committed to public interests, but all for-profit organisations are not necessarily going to defend a narrow self-interested agenda either. And it is not obvious that defending a self-interested agenda justifies being ruled out as a legitimate law-making actor. In the end, indeed, as we argued in the previous section, even certain states and IOs may actually be less committed to the advancement of global collective or general interests than others. ${ }^{63}$

Thus, the only way to get more conceptual clarity is to adopt an extensive and allinclusive notion of civil society actors, one simply defined by opposition to statist or public actors. ${ }^{64}$ This fits the traditional idea of civil society, as 'a rather diffuse,

\footnotetext{
${ }^{60}$ Peters, 'Global Constitutionalism Revisited' (n 47) 56.

${ }^{61}$ De Búrca, Keohane and Sabel, 'New Modes of Pluralist Global Governance' (n 47) 784; Peters, 'Global Constitutionalism Revisited' (n 47) 56; 'Dual Democracy' (n 47); 'Are We Moving Towards Constitutionalization of the World Community?' (n 47); Bohman, 'Democratising the Global Order' (n 47).

${ }^{62}$ Alexander, The Civil Sphere (n 52); Benjamin Barber, Jihad vs McWorld: How Globalism and Tribalism are Reshaping The World (Ballantine Books 1996) ch 1. In fact, according to some authors, this inclusiveness of the concept of civil society is partly responsible for the discredit that, at least among socialists and Marxists, has plagued that idea for decades. In that context, any vindication of its role was immediately associated with the privatization of public power. See John Keane, Democracy and Civil Society: On the Predicaments of European Socialism, the Prospects for Democracy and the Problem of Controlling Social and Political Power (Verso 1988); Alexander, The Civil Sphere (n 52) 26-29.

${ }^{63}$ Besson, 'Community Interests in International Law' (n 43).

${ }^{64}$ Cohen and Arato, Civil Society and Political Theory (n 52).
} 
umbrella-like concept referring to a plethora of institutions outside the state ${ }^{65}$ Following Keane, we might consider that '[c] ontrasted with government, civil society [means] a realm of social life - market exchanges, charitable groups, clubs and voluntary associations, independent churches and publishing houses - institutionally separated from territorial state institutions' ${ }^{66}$ Extending this broad understanding of civil society to the global sphere, Keane proposes to conceive of global civil society as an ideal-type concept that refers to 'a dynamic non-governmental system of interconnected socio-economic institutions that straddle the whole earth, and that have complex effects that are felt in its four corners'. ${ }^{67}$

In sum, transnational or global civil society actors would be defined negatively as all those who are not public actors, in the sense of not having received their powers institutionally from a sovereign people. This wide definition leaves open the normative issue of deciding which of those civil society actors should be given the right to participate in what international law-making context. Any normatively attractive account of the DM would have to provide a clear criterion to identify which private actors should be regarded as legitimate in each context. All we can say at this stage is that the proponents of the DM have not yet provided such a standard.

A second conceptual problem with the DM is that it also lacks a clear and concrete definition of the PCSP. As a result, that principle lies mostly implicit in the literature. Proponents of the DM have not said much indeed about the exact way in which civil society actors are supposed to interact with states and other public actors. As stated above, the adoption of a PCSP necessarily implies a reconsideration of the traditional PSC, but the way in which such a reconsideration should work out remains far from clear. Apart from the few examples authors give when drawing from the practice of international law-making, defenders of the DM remain very vague about the concrete articulation or combination of public and private actors, and whether, in particular, their combinations should vary from one context to another. ${ }^{68}$

The only criterion for combining both kinds of actors that has been explicitly put forward is the following. Some proponents of the DM seem to hold that only statist actors may be entitled to give or deny consent, while civil society actors may contribute in several other ways to the previous stages of decision-making processes, and especially to enhancing not only inclusion but also deliberation. ${ }^{69}$ On this view, they may be considered to have voice, but no vote, which seems to entail a clear distribution of roles. ${ }^{70}$ The problem with this conception of the DM is that it comes dangerously close to the SM in practice and limits drastically the complementary benefits of the DM. In any case, it does not fit the current practice of international law-making where civil society actors are given actual law-making powers. Besides, the distinction between vote and voice is of little help when processes of law creation are not highly institutionalised.

\footnotetext{
${ }^{65}$ Alexander, The Civil Sphere (n 52) 24.

${ }^{66} J$ ohn Keane, 'Civil Society, Definitions and Approaches' in Helmut K Anheier and Stefan Toepler (eds), International Encyclopedia of Civil Society (Springer 2010) 1.

${ }^{67}$ Keane, Global Civil Society? (n 2) 8.

${ }^{68} \mathrm{~A}$ first step in this direction is made, for instance, by de Búrca, Keohane and Sabel who identify four conditions to be filled on the side of statist actors in order for experimentalist governance to be minimally successful. See de Búrca, Keohane and Sabel, 'New Modes of Pluralist Global Governance' (n 47) 781-83; 'Global Experimentalist Governance' (n 47) 484.

${ }^{69}$ De Búrca, Keohane and Sabel, 'Global Experimentalist Governance' (n 47) 484.

${ }^{70}$ Peters, 'Dual Democracy' (n 47).
} 
Quite often, indeed, they do not involve a formal voting process, but nevertheless different actors may play a significant role in the determination of the law by participating in discussions or negotiations of legal drafts.

This general lack of specificity of the DM with respect to the type of civil society actors that should be authorised into international law-making processes, as well as the way(s) in which such actors should be left to interact with states and public actors in general is to be expected, considering that this is a relatively new view. It has only just emerged in international law theory, and has concentrated so far on criticising the traditional SM, on turning the increasing role of civil society actors in international law-making in practice into a normative claim, and, therefore, on construing normatively that claim mainly negatively in reaction to the SM. The time has come, however, to bring more positive answers to those questions, and this will be the task of section 7 .

Before developing our own model for the refinement of both the SM and the DM, a few words should be said about a second set of deficits of the DM, shortcomings that pertain to the principles of democratic legitimacy identified in section 2 .

\section{Shortcomings of the Dualist Model}

According to the DM, civil society actors have to interact and collaborate with statist actors in international law-making with the aim of improving its democratic legitimacy. More specifically, they, at least, have to contribute to overcoming some of the democratic deficits of the PSC identified in section 4 or, alternatively, to come up with other ways to implement the three democratic principles mentioned in section 2, i.e. ultimate, effective popular control, political equality and deliberative contestability.

Regrettably, however, the DM and the PCSP are not free from democratic shortcomings of their own, and in particular: lack of representativeness (6.1), political inequality (6.2) and lack of deliberative contestability (6.3). ${ }^{71}$

\subsection{Lack of representativeness}

The SM and the PSC face two main deficits in terms of representativeness: the existence of non-democratic states and the difficulty to hold even democratic states' governments accountable for their foreign policy. Some of those shortcomings or even all of them may be compensated by civil society actors. Chinese and transnational NGOs may work together to promote human rights and democracy in China and may bring international institutions to take firm decisions and actions that can put some pressure on China's government to make the adequate internal reforms. Similarly, global environmentalist NGOs, as well as other civil society organisations may offer better advocacy to promote the interests of environmentalists from all around the world, and push for a more advanced climate change agenda on the international plane than the democratic governments of most states.

\footnotetext{
${ }^{71}$ Some of those democratic shortcomings apply to civil society actors domestically as well, while others are specific to their participation in international decision-making or, at least, are magnified in the global context. What this means, of course, is that fixing them on the international plane may have consequences on the domestic one, and vice versa.
} 
However, even if civil society actors mostly do a good job in defending such unrepresented views or claims, this is not enough in itself to consider them legitimate representatives of the relevant people(s).

The difficulty indeed is that civil society organisations are unable to meet the representativeness requirement of ultimate, effective control by those they allegedly represent. They are actually even less capable of doing so than statist actors. These organisations may claim to represent the unrepresented or those insufficiently represented by the current international system. However, claiming so does not automatically make them legitimate representatives. They have not been democratically elected, whether domestically or globally. Most of them are not even minimally transparent or accountable. And this is even worse when we talk about other kinds of civil society organisations than NGOs, such as lobbies, corporations, churches, or less salient civil associations. It is unclear how the Chinese and the Spanish citizens could exert ultimate control over what those NGOs and organisations are doing. And so are the procedures for them to react when they disagree with the concrete aims those organisations are pursuing, with the means they are using, or with the constraints they place on themselves.

\subsection{Political inequality}

The SM and the PSC suffer from at least four deficits in terms of political equality: the disproportions in demography, the imbalance of informal power among states, the problem of permanent minorities, and the unequal distribution of views. Global civil organisations might contribute to alleviating some of them.

For instance, the people of largely populated states whose power in international relations might be proportionally lower to those of scarcely populated ones - by virtue of state equality under international law - might certainly aspire to use civil society organisations to try to compensate their power imbalance. Their proportion of power in civil society would presumably be more in line with their size in population, and that means that they would have more chances to influence the outcome of the international decision-making process. The people of less economically or militarily powerful states or of those who belong to permanent minorities might similarly aspire to the assistance of NGOs in order to counterbalance the excessive power of other states or groups of states.

All the same, even an international law-making system in which civil society organisations exercise some or even significant power faces important difficulties of its own in terms of political inequality.

Indeed, global civil society does not represent equally the interests of all people(s). First of all, some social groups are more culturally powerful than others, and have more power to organise better advocacy. Economic inequalities, for instance, can translate into unequal chances to get good advocates internationally, especially considering that international participation is costly, even more so than in domestic contexts. ${ }^{72}$ Not surprisingly, civil society organisations of less powerful countries, and of those that usually fall into permanent minorities, are actually less present and salient, and therefore less influential, in international debates. Second, certain private groups, even if not

${ }^{72}$ Carole Pateman, The Sexual Contract (Polity Press and Stanford UP 1988). 
particularly more powerful in economic or cultural terms, are simply better organised and more mobilised than others. Some social groups are actually even reluctant about organising themselves and creating civil society organisations to represent their interests, or actually less capable of doing than so others. Human rights and democracy activists in China or in Congo have lower chances to find good advocates of their interests and claims in international law-making processes than citizens from the US or Germany. But even if civil society organisations based in the US and Germany claim to represent those citizens in China and Congo, those citizens, again, have less means to keep those organisations under control than their counterparts in the US and Germany.

Thus, even if we take civil society actors to be sufficiently representative of certain people(s), some civil society actors are more influent and powerful than others, and some individuals or groups are not even represented by any of them. As a result, a decision-making process in which people(s) are supposed to be represented only by civil society organisations could end up being discriminatory or, at least, be unable to ensure full respect for the principle of political equality.

\subsection{Lack of deliberative contestability}

The SM and the PSC also suffer from important weaknesses in terms of deliberative contestability, and in particular with respect to the use of veto, the lack of expertise and the neglect of collective interests. The inclusion of global civil society organisations might, again, contribute to alleviating some of them.

In the absence of global elections and other traditional mechanisms to hold international institutions accountable, opening our processes of international decision-making to the participation and contestation of global civil society actors can contribute to developing a sustained, dynamic, pluralist and rich deliberation in the global public sphere, ${ }^{73}$ and hence to developing alternative forms of democratic accountability. For instance, if state governments have strong incentives to negotiate international policies on climate change from the narrow perspective of their respective economic interests, and therefore to avoid a genuine debate based on expert evidence, the exchange of reasons and the inclusion of global collective interests, civil society organisations may press them to face such evidence, provide arguments or justifications for what they do or omit to do and relate to the general interest. The Spanish citizen in our example may therefore consider those organisations as good allies to foster genuine international deliberation.

Nevertheless, the mere participation of a civil society actor in international law-making is not enough to conclude to its beneficial effects in terms of deliberative contestability.

First of all, defenders of the DM, like Keohane, Sabel and de Búrca, actually recognise that experimentalist processes such as those they defend as paradigmatic of the DM 'can be captured by groups with hidden agendas. ${ }^{74}$ As a matter of fact, any mechanism and opportunity of contestation can be used or abused for the strategic purposes of a given private actor. Thus, the positive effects of the PCSP are conditional, at least, on the type

\footnotetext{
${ }^{73}$ Habermas, Between Facts and Norms (n 52); The Postnational Constellation (n 52); Bohman, 'Democratising the Global Order' (n 47); James Bohman, 'Democratizing International Law: A Republican Reading of Habermas' Cosmopolitan Project' in Tom Bailey (ed), Deprovincializing Habermas: Global Perspectives (Routledge and Taylor \& Francis 2015).

${ }^{74}$ De Búrca, Keohane and Sabel, 'New Modes of Pluralist Global Governance' (n 47) 784.
} 
of civil society actors and the kind of motivations they have. Not all civil society organisations can be legitimate actors of international law-making. And not all kinds of motivations are compatible with a legitimate intervention of those actors in processes of international law-making. The main difficulty is that, as we saw in section 5, there is no clear independent criterion, as of yet, to select ex ante the kind of civil society actors that are going to be beneficial to deliberative contestability.

In addition to the difficulty of identifying legitimate civil society actors, the quality of a deliberative process does not only depend on the type of actors taking part in it and the kind of motivations and dispositions they have. It also depends, second, on having the right number of participants, disposing of adequate resources, and structuring the deliberation in the right way, in order, for instance, to distinguish between different forms of participation. As discussed in the previous section, however, promoters of the DM have not yet developed sufficient criteria regarding the best ways of combining public and private actors in international law-making institutions and processes. We are still at loss, therefore, about how best to regulate such combined international law-making procedures.

In conclusion, the contribution that the PCSP can make to legitimate international lawmaking is conditional upon its success in overcoming those democratic shortcomings, and the DM should be refined to provide such an account (see section 7.3).

\section{Multiple representation in international law-making}

The two main models discussed so far, and their respective answers to the question of the identity of the legitimate actors of international law-making face important deficits in terms of democratic legitimacy. Some of them can be alleviated or even overcome, but only, we would like to argue now, within a complex model of representation that refines each of them by reference to the other and then combines them both. The view underpinning that model of complex representation in international law-making may be coined the Multiple Representation Model (MRM). It is admittedly a variation of the $\mathrm{DM}$, but a qualified one.

After presenting what multiple representation amounts to (7.1), we explain how each of the components from the SM and the DM that it combines may be mutually refined to overcome their respective democratic shortcomings (7.2 and 7.3).

\subsection{The Multiple Representation Model}

The only way to overcome the democratic deficits of current international law-making, we propose, is to articulate a model of multiple democratic representation. The proposed model transcends the simple duality used to refer to the relationship between statist actors and civil society, ${ }^{75}$ and approaches representation in international law-making as both a multilevel and a multidimensional scheme of political representation.

\footnotetext{
${ }^{75}$ Samantha Besson, 'Ubi lus, Ibi Civitas: A Republican Account of the International Community' in Samantha Besson and José Luis Martí (eds), Legal Republicanism: National and International Perspectives (OUP 2009); Peters, 'Dual Democracy' (n 47); Kuyper, 'Global Democratization and International Regime Complexity' (n 47); 'Systemic Representation' (n 47).
} 
Of course, a certain degree of duality is preserved on the proposed model, since we claim that two types of actors, public and private, under specific conditions, should be able to act legitimately in a two-tier system of representation of people(s).$^{76}$ Still, the actors on each side are much more diverse than alleged in either the SM or the DM, on the one hand, and they combine with one another in multiple ways that still need to be explored, on the other. This is why the proposed representation model is 'multiple': both in the many levels of representatives available amidst public and private representatives and in the multidimensional relations between them.

Starting with statist actors, the SM is right in emphasising the value of the existence of self-governing sovereign political communities. As we argued in section 3 , the principles of democratic legitimacy require us to pay tribute to domestic self-government by endorsing some version of the PSC. However, the traditional statist view has not provided a sufficiently democratic account of the legitimate public actors of international law-making. The MRM, by contrast, proposes a revised account thereof that is both narrower and broader at the same time. ${ }^{77}$

The MRM advocates a more restrictive view of the public actors of international lawmaking because it only recognises as fully legitimate those public actors that are territorially delineated and democratically organised with respect to the principles of legitimacy discussed in section 2 - that is, when they can claim to represent the people(s) that have delegated the relevant powers to them in the exercise of their sovereignty and have kept the ultimate, effective control over them, and when they respect the principles of political equality, deliberative contestability and human rights. Other public actors, in our view, are not sufficiently legitimate or not legitimate at all to determine something as important for our lives as international law-making.

At the same time, however, the MRM broadens the scope of public actors in a way that transcends the traditional conception of the SM, which has been limited to this date to states and state-based IOs. The value of self-governing sovereign political communities that underlies our commitment to public actors as legitimate can be instantiated in forms of political organisation other than states. There is indeed a plurality of statist

\footnotetext{
${ }^{76}$ Interestingly, the MRM may also be considered as dualist in a deeper sense. Following what Habermas has defended for the EU, and extending it to the international system, the MRM is inspired by cosmopolitan ideals, and in that sense endorses the direct global sovereignty of all human beings. See Jürgen Habermas, 'A Political Constitution for the Pluralist World Society?' (2013) 40 Journal of Chinese Philosophy 226; 'European Citizens and European Peoples' (n 47). They all share, qua individuals, a fundamental interest in living under a non-dominating, but effective international system that deals with all their global concerns and problems, like wars, massive human rights violations, the threat of nuclear weapons, or climate change. See also Kumm, 'Constituent Power' (n 47). This is one of the grounds for the inclusion of civil society actors in international law-making processes. At the same time, however, there is a fundamental value in the existence of self-governing sovereign political communities. They amount to more than intermediaries or representatives between the people and the international system. The way to pay tribute to the fundamental value of domestic self-government is by recognising political communities as co-sovereigns of the international system. What this means is that the international system would not only have two types of legitimate actors or representatives (statist and civil society actors), but also two different types of sovereigns: the sum of all human beings, on the one hand, and the sum of all public entities that represent sovereign territorially based publics, on the other. The details of this deeper duality of the MRM will be articulated in a separate paper.

${ }^{77}$ Some sophisticated proponents of the SM have recently defended more restrictive accounts of the legitimacy of public actors along the lines argued in this article. See, for instance, Christiano, 'Democratic Legitimacy and International Institutions' (n 7); 'The Legitimacy of International Institutions' (n 7); Pettit, 'Legitimate International Institutions' (n 7); 'The Republican Law of Peoples' (n 14). The MRM differs from those accounts, however, by virtue of it broader scope, and in particular the fact that it includes other public actors than states and state-based IOs, but also combines them to civil society actors in more than just a remedial way. Contra, see Christiano, 'Democratic Legitimacy and International Institutions' (n 7) 134-35.
} 
actors, besides state governments, that do and should represent people domestically, and this does and should also apply to their representation in international relations and in the making of international law. Some are infra-national, such as cantons, regions or cities, while others are supra-national, such as evolved or state-like IOs.

Importantly, the claim is not only that IOs have adopted a variety of forms, many of which have not always preserved their state-based nature. As a result, it is not only about the emergence of supra-national regional organisations, such as the EU, that do not only represent the aggregate interests of their member states. Rather, some of the most important innovations come from the fact that infra-national territorial units, such as cities, federated states or regions, are gaining in international visibility and power and pursuing their own agenda. Take the example of the Global Parliament of Mayors, a network of cities from all around the world, created in September 2016 in The Hague. It is not the only or first international network of cities, but it has been created with the explicit purpose of becoming a powerful actor of global governance and one through which cities try to circumvent states and their interests. ${ }^{78}$

Think again of the case of the Spanish citizen concerned about climate change. According to him, the Spanish government is not doing enough to advance an international environmental agenda. However, that citizen, who happens to live in Barcelona, might feel better represented, at least on this issue, by the Mayor of Barcelona who is trying to mobilise several other major European cities to take joint action, conclude collaboration agreements, and put pressure on state governments. The City Council of Barcelona may therefore be considered as a public actor in the MRM of international law-making. ${ }^{79}$

Thus, the correct way to approach legitimate public actors in international law-making is by taking the full measure of the multilevel, overlapping sovereignties ${ }^{80}$ that characterise the international system and can operate through a multiplicity of public representatives. ${ }^{81}$ This proposal actually fits and justifies the existing practice in the international law of treaties. The latter does not preclude that infra-national entities may be vested with the right to conclude international treaties with other corresponding foreign infra-national entities in areas that correspond to the respective domestic allocation of powers (arts 8 and 46 VCLT), as in Switzerland where cantons are considered as sovereign by the constitution and may conclude international agreements.

\footnotetext{
${ }^{78}$ Benjamin Barber, If Mayors Ruled the World: Dysfunctional Nations, Rising Cities (Yale UP 2013); Benjamin Barber, Cool Cities: Urban Sovereignty and the Fix of Global Warming (Yale UP 2017).

${ }^{79}$ Technically speaking, the City Council of Barcelona receives its legal powers from the Spanish Constitution. However, it would be a mistake to think that all its power comes from the Spanish people as the only sovereign in the country. The people of Barcelona can also claim to be sovereign about the international agenda that their mayor should pursue. Thus, in case of disagreement between Barcelonians and other Spaniards about the most adequate international policy to adopt regarding climate change, the rest of the Spanish people should not be able to impose an agenda onto the Mayor of Barcelona, just as the citizens of Barcelona should not be able to impose an international agenda unilaterally onto the Spanish Government.

${ }^{80}$ In a separate article, we will argue that the traditional Hobbesian, unitary or monist conception of sovereignty that has been central to the development of the SM is no longer capable of capturing how our increasingly complex and changing world is structured. We will also argue that, as republicans have always held, there are normative reasons to prefer a fragmented or dispersed account of sovereignty: see, for instance, Pettit, On the People's Terms (n 10) ch 3.

${ }^{81}$ Our understanding of how such a multilevel system should be articulated needs to be developed. What it should entail in particular is clarity on the balance between the different kinds of public actors, and whether different combinations might be appropriate for different issues and for different contexts of international law-making. What is clear, however, is that answers to the question of the legitimate actors of international law-making should be specific to the different institutions, processes, conditions and circumstances with and in which they are involved. In short, they should be tailormade, so as to prevent domination. See Kuyper, 'Global Democratization and International Regime Complexity' (n 47).
} 
In short, the MRM implies both a much more restrictive view of the public actors that can be recognised as legitimate by reference to the endorsed principles of democratic legitimacy, and, within those constraints, a much broader view of different overlapping, sovereign publics represented by different forms of public actors, all organised in a complex, multilevel system.

Even this revised understanding of public actors of international law-making does not ensure the democratic legitimacy of the system, however. Indeed, many of the democratic shortcomings identified in section 4 remain unaddressed.

In agreement with the proponents of the DM, therefore, we find it necessary to open up international law-making processes to a new kind of actors, that is, to private actors coming from civil society. In effect, a global public sphere in which a deep, sustained, dynamic public debate takes place, fed by a vibrant global civil society, is a condition for the democratic legitimacy of the international system. It is important, however, that global civil society actors be empowered to participate not only in an informal, non-institutional public deliberation, but also in more formal settings and procedures of international decision-making. In that sense, they should be allowed to interact with public actors as well as with international institutions. And they should be able to do it not only as watchdogs of the legitimacy of such institutions that can actually contest the decisions that have been made or the actions that have been taken, but also as active participants - and therefore as partial authors - of international law-making, especially in representation of the interests, views and claims of those people(s) who do not find adequate representatives among public actors.

The MRM differs from the usual understandings of the DM in two respects, however. It relies both on a broader understanding of the private actors that might be invited to participate in international law-making processes, and on a more restrictive one in terms of the strict conditions that such actors should meet to be fully legitimate actors of international law-making.

The proposed model of international representation is broader than the DM's because, for the reasons explained in section 5 , we do not consider that one should rule out private actors ex ante, for instance by reference to their form of organisation (more or less formalised), their apparent motivations (non-profit $v s$ for-profit), the nature of their normal activities (political and cultural vs economic), or their territorial scope (local, national, transnational, or global), at least on a general basis. Any private actor, collective or individual, local or global, should in principle be a candidate to contribute to international decision- and law-making. The general principle to be applied here should be that, ceteris paribus, the wider and more plural the involvement of the civil society in several aspects of international law-making, as well as in the implementation and enforcement of such law, the better for the democratic legitimacy of the system as a whole.

As we argued in section 6, however, a broad, unqualified version of the PCSP suffers from several democratic shortcomings of its own. One should aspire to address them in order not to exacerbate or multiply the democratic deficits plaguing the SM, by merely adding some more with the PCSP. What this means, more specifically, is that every setting and procedure of international law-making should be designed so as to comply with the requirements of democratic legitimacy articulated in section 2. Some additional restrictions might also be justified depending on the context. For instance, civil society actors considered as legitimate in participating in World Trade Organisation (WTO) 
decision-making procedures may not be the same as those considered legitimate in taking part in World Health Organisation (WHO) decision-making. As a matter of fact, practical reasons of feasibility should bring most contexts to be highly selective of the private actors allowed to participate. The exact selection of which concrete private actors should be allowed to participate in a given context of international law-making should therefore be decided in a particularistic way. However, in each context, the only acceptable criteria used to differentiate between private actors or to condition their participation should be the four principles of democratic legitimacy presented in section 2 .

In short, the MRM proposes an account of both public and private legitimate actors of international law-making that is both broader and more restrictive than both the SM and the DM taken together. It approaches the participation of a plurality of public and private actors in terms of their capacity to represent the people(s) that are affected by international decision-making. On that basis, it argues for an international system of representation that combines different levels and dimensions of democratic representation, each of them mirroring the other and trying to refine it.

In this sense, the MRM comes close to the idea of systemic representation, according to which different representatives and different types of representation may all have a role to play in an overarching system as long as their sum and interaction produces a fair and adequate amount of global or systemic representativeness. ${ }^{82}$ The plurality of the system is one of its key factors. This is why defending a more generous account of the kinds of actors allowed to intervene is important. However, it is essential not to forget that the final purpose of the whole system is to ensure that the people(s) affected by the decisions and laws to be made are democratically represented. With that purpose in mind, it is crucial to remember that the plurality of both public and private actors is insufficient in itself to secure democratic legitimacy, unless these actors are combined in the adequate way through complex institutional design that cannot but be contextual.

In order to do so, both the PSC and the PCSP need to be revised. On the multidimensional model of international representation defended in this article, they should be refined in combination with one another in order to make international law-making fully legitimate. Rather than constituting a simple dual scheme of international representation, the revised PSC and PCSP should be approached together as producing a complex system of multiple representation.

\subsection{A refined version of state participation}

In the MRM, statist actors may only play a significant role in international law-making, provided some of the democratic shortcomings of the PSC identified in section 4 are addressed.

This should not only be done through various domestic and international reforms of the PSC, ${ }^{83}$ but also in the broader framework of the MRM and hence in combination

\footnotetext{
${ }^{82}$ For a complete account of the idea of systemic representation, see Jane Mansbridge and Felipe Rey, 'The Representative System' (unpublished paper presented at the 13th National Congress of the Association Française de Science Politique, Aixen-Provence, 2015). For its direct precedent, Jane Mansbridge and others, 'A Systematic Approach to Deliberative Democracy' in John Parkinson and Jane Mansbridge (eds), Deliberative Systems: Deliberative Democracy at the Large Scale (CUP 2012). For another account, albeit slightly different, see Kuyper, 'Systemic Representation' (n 47). The exact way in which the MRM endorses that idea of systemic representation will be developed in a separate article.

${ }^{83}$ Besson, 'Law Beyond the State' (n 21); Martí, 'Sources and the Legitimacy of International Law' (n 1).
} 
with the PCSP. The outcome should be a more democratic understanding of the PSC as a Principle of State Participation (PSP), which may or may not include consent stricto sensu, depending on the contexts in which statist actors operate and how state participation combines with the participation of civil society actors.

With respect to the issue of democratic representation, first of all, the non-democratic state critique is the hardest to address. Indeed, either the PSP only benefits democratic states, at the expense of equality with individuals in non-democratic states, or, if it is generalised to all states, it enables the agenda of non-democratic states to dominate democratic ones', at the expense of individual equality and representation again, but, this time, within democratic states.

The least objectionable answer, from a democratic representation perspective, is to grant the right to invoke or oppose one's state consent to democratic states only. ${ }^{84}$ This is also the only way to account for the minimal democratic legitimacy standards that arise from state practice in international law (e.g. jus cogens human rights norms and non-discrimination principles), and that claim to bind democratic states even without or against their consent. ${ }^{85}$ Exercising one's right to dissent in international law-making and to contribute actively to the latter should constitute a sufficient incentive for nondemocratic states in practice. In any case, it is a duty under international human rights law, but also under the international principles of equality and of democracy in international customary law, for non-democratic states to become minimally democratic and a responsibility of other states to support those states in their efforts to democratise.

The restriction of the scope of states whose consent may matter legitimately could be counterbalanced, through the involvement of civil society representatives as discussed in section 7.1, but also by other ways of taking the interests of non-democratic states' populations into account. One may think, in particular, of designing domestic institutions, and especially state governments, so as to require from them that they consider global collective interests shared with other people(s) around the world, and not only domestic ones. The design of international institutions could also be such that those interests are represented. One may think of the design of international courts and judicial procedures, in particular. ${ }^{86}$

A second issue with representativeness through state consent, on the domestic side this time, is the potential lack of domestic accountability of state governments. This concern could be alleviated by working on domestic foreign relations law and, in particular, on setting up domestic institutional mechanisms geared towards making all international law-making matters an object of internal deliberation and decision-making. One may think, for instance, of submitting the internal approval of international treaties, but also the release of international negotiation mandates of the state government to parliamentary procedures that equate internal legislative ones, of the creation of specifically elected offices in charge of international affairs, or even of organising (optional or compulsory) popular referenda on signed treaties.

\footnotetext{
${ }^{84}$ Buchanan and Keohane (n 7); Christiano, 'Democratic Legitimacy and International Institutions' (n 7); Besson, 'State Consent and Disagreement in International Law-Making' (n 11).

${ }^{85}$ Martí, 'Sources and the Legitimacy of International Law' (n 1); Besson, 'Law Beyond the State' (n 21); Allen Buchanan, 'Reciprocal Legitimation: Reframing the Problem of International Legitimacy' (2011) 10 PPE 5, 15-16.

${ }^{86}$ Besson, 'Community Interests in International Law' (n 43).
} 
As to the concern of political equality, second, and in order to counterbalance the problem of demographic inequality, a solution could be to develop requirements of proportional representation of the actual population of states or population-based qualified majorities in the decision-making process of international institutions, such as international courts, multilateral treaty-conferences or states parties' assemblies. ${ }^{87}$

Second, the concern about the imbalance of power among states could be addressed not only through the creation of strong coalitions of less powerful (e.g. poor) states that may be able to counterbalance the bargaining strength of powerful (e.g. wealthy) ones, ${ }^{88}$ but also by working on the source of that power imbalance itself, and in particular on poverty, the resource curse and so on. With respect to the problem of permanent minorities, third, inspiration could be found within domestic democratic practice where similar problems arise around the issue of the tyranny of the majority. ${ }^{89}$ Thus, one may mention, as potential remedies, international judicial review or consociational correctives (e.g. regional ones as in most United Nations [UN] bodies like the Human Rights Council or Human Rights Treaty-Bodies, but also linguistic or gender-based ones) in international legislative conferences or states parties' assemblies, but also the constitution of transnational coalitions of states or individuals around certain issues such as environmental ones in particular.

With respect to the unequal distribution of views entrenched through state consent and the one state, one vote model, finally, similar solutions to the previous ones could be suggested. Regrettably, however, even a revised PSP is likely to perpetuate the unequal representation of unequally distributed views as long as it is not replaced by a one person, one vote model, due to the lack of transitivity between individual and state equality.

Finally, with respect to the critique of deliberative contestability, many refinements of the PSC could be proposed.

A first solution could be to enhance the participatory dimension of state consent in international law-making. As a matter of fact, state consent is not always used negatively as a veto, but also, in a non-voluntarist way, as a form of participation in international lawmaking, ${ }^{90}$ thereby confirming the feasibility of the proposed re-interpretation of the PSC as PSP. This comes out clearly from the recent international treaty law-making practice, and in particular from the increasing use of consensus-shaping before votes are taken and the growing recourse to adopting memoranda of understanding as intermediary deliberative products before treaties are concluded.

The deliberative dimension of the PSP is even more clearly at play in the context of the interpretation and enforcement of international treaties by both domestic and international institutions. For instance, this is already what is required by the reference to 'subsequent state practice' in the interpretation of international treaties (art 31(3)(b) VCLT). Referring the domestic or international interpreter of international treaties to what has become of the original state consent in that state's and other states' legal practice since the treaty was concluded is a way of thickening the reasoning supporting it and making it more deliberative. Another example may be the justification requirement imposed on

\footnotetext{
${ }^{87}$ Martí, 'Sources and the Legitimacy of International Law' (n 1).

${ }^{88}$ Christiano, 'Replies' (n 16) 227; 'The Legitimacy of International Institutions' (n 7); 'Democratic Legitimacy and International Institutions' (n 7).

${ }^{89}$ Christiano, 'Democratic Legitimacy and International Institutions' (n 7) 133-34.

${ }^{90}$ Besson, 'Law Beyond the State' (n 21); 'State Consent and Disagreement in International Law-Making' (n 11). Contra, see Christiano, 'Climate Change and State Consent' (n 28); 'Replies' (n 16).
} 
states' interpretations of the European Convention on Human Rights by the European Court of Human Rights (ECtHR). ${ }^{11}$ Requiring states to give reasons for their human rights interpretations, and taking those into account in the Court's decisions when assessing how states' initial consent has evolved substantially since then, are ways of bringing more reasons into the practice of state consent and to making it thereby more deliberative over time. The same may be said of the ways in which state consent is given in the making and determination of customary international law that occurs through state (legal) practice, and in particular the reasoning of domestic courts.

Another set of correctives to the deliberative shortcomings of state consent may be to enhance its epistemic qualities. There are ways to accommodate the need to resort to experts while justifying the democratic role of the PSP in international law-making. This can be exemplified in practice by the development of certain regimes of global administrative law. ${ }^{92}$ One should make sure, however, that the aims and principles that guide the experts called to contribute to international law-making are themselves identified by formal sources of international law and hence respect the PSP. Ultimate democratic state control is key, indeed, if one is to avoid forms of global technocracy and domination. ${ }^{93}$

Finally, the representation of the global collective interests of the people by state governments under the PSP and, accordingly, their contribution to the deliberation may be secured through stronger procedural mechanisms of accountability of the executive on all matters international, as we explained before. As a matter of fact, developing transnational comparison in international legal interpretations and determinations to make sure state consent becomes less of an individual veto and more of a collective deliberative force is already at play in some international judicial practices. It may be exemplified by the ECtHR's transnational human rights consensus test, in particular.

All these are just examples of how the PSC could and should be adequately limited, circumscribed, and regulated in order to be able to make a legitimate contribution to international decision- and law-making and become a truly participatory principle. Importantly, as we explained in section 6, many of those refinements of the PSP necessarily require the association of civil society actors to the extent that the DM actually arose out of the need to compensate for the democratic shortcomings of the SM. As a result, revisions of the PSP should also be combined with the revisions of the PCSP proposed in the next section.

Of course, as we explained before with respect to the multiplicity of statist actors, their combinations and the exact ways in which public and private representatives complement one another are necessarily particularistic and will differ from context to context. Importantly, we cannot exclude a degree of circularity in the ways in which the revised PSP and PCSP respond to one another, and even a failure, in some cases, for them to complement one another effectively, as a result of the heterogeneity of the causes of their respective shortcomings. ${ }^{94}$ The risk of such a failure, which might lead to the aggregation of

\footnotetext{
${ }^{91}$ Samantha Besson, 'Human Rights as Transnational Constitutional Law' in Anthony F Lang, Jr and Antje Wiener (eds), Handbook on Global Constitutionalism (Edward Elgar 2017).

${ }^{92}$ Krisch (n 22).

${ }^{93}$ Besson, 'State Consent and Disagreement in International Law-Making' (n 11).

${ }^{94}$ Thanks to Richard Bellamy for drawing our attention on the danger of double-inclusion of certain civil society organisations on the proposed model, for instance through early state intervention in organising civil society participation, and hence giving them 'two bites of the cherry', as it were.
} 
various shortcomings, rather than to their mutual neutralisation or alleviation, is certainly one of the effects that the specific design of the MRM in each respective context of international law-making should keep in mind and try to avoid.

\subsection{A refined version of civil society participation}

In the MRM, civil society actors may only play a significant role in international lawmaking, provided some of the democratic shortcomings of the PCSP identified in section 6 are addressed in the broader framework of the MRM and in combination with the refined PSP.

The main problem of democratic legitimacy that civil society actors face is their lack of representativeness.

For a civil society organisation to be conceived as a democratic representative of a certain social group, it is not enough that that organisation claims to be a representative. ${ }^{95}$ Of course, one should not expect that members of that social group have previously elected or appointed the relevant civil society organisation, as it would be the case in the electoral representation of most public actors. What is required, however, is that the allegedly represented social group can rely on effective mechanisms to exert ultimate control over what its would-be representatives do or decide. Nowadays, most civil society organisations lack the necessary features to secure that kind of ultimate, effective control of the people(s) they claim to represent.

Such deficits in terms of representativeness may not necessarily be fatal depending on the exact role civil society actors are playing in specific international law-making processes. If all they are allowed to do is attend some meetings and perhaps have a voice in the deliberations, complying with the principle of ultimate, effective popular control may not be that relevant. However, insofar as they become more active actors, and take part in negotiations or drafting discussions, or even directly in voting procedures, they should guarantee their representativeness by adopting certain internal provisions and mechanisms. The more active the role civil society actors are allowed to play in the process, the stricter their duty to be under the ultimate, effective control of the people they claim to represent.

There are, at least, two different ways in which the ideal of ultimate, effective control could be approached in this context. In certain circumstances, first of all, it may not be unrealistic to hold elections of civil society organisations by the people(s) they claim to represent whether domestically or globally, on the model of trade union elections, for instance. Organising electronic elections, secured, for instance, through blockchain, for differentiated issues in diverse settings is feasible. A second strategy to alleviate the lack of representativeness of civil society organisations could be to impose certain requirements on them of the kind that apply to states and state-like/state-based organisations: namely, requirements of transparency, external accountability, internal democracy etc. For instance, civil society organisations should openly explain to everyone, or at least to those whom they claim to represent, the actions and policies they plan to defend in their international actions, and they should set up ways to be held accountable by the people they claim to represent. To do so, they could allow external petitions, promote

\footnotetext{
${ }^{95}$ Contra, Kuyper, 'Global democratization and international regime complexity' (n 47); 'Systemic Representation' (n 47).
} 
open debate, allow for the contestation of their actions, or even launch open consultations. The best way to secure the representativeness of these actors may, actually, be to subject them to scrutiny and control through a system of rules designed by states and IOs and by other public actors involved in the international law-making process.

Both strategies should be promoted or implemented by states and IOs, i.e. public actors, in the ways their constituencies find most appropriate. Again, their success depends on a virtuous equilibrium between the PSP and the PCSP.

Think of the case of the Chinese citizen who is left unrepresented internationally by the Chinese government. This is one of the hardest cases from the point of view of adequate democratic representation. The deficit of representation that this citizen suffers might be alleviated by opening up the decision-making process to certain civil society organisations, some of which may come directly from China, while others may simply have a transnational or global constituency. This Chinese citizen may exert some control over such organisations, especially insofar as they are fully transparent and roughly accountable for what they do and defend in those formal settings. No form of control on her part, though, can be sufficiently effective and ultimate. Thus, the best approximation to the ideal of ultimate, effective control is to let the other public actors involved, at least the ones that are democratically legitimate on our proposed account, impose adequate rules and constraints on the civil society organisations in question, aiming at ensuring that the latter effectively represent the interests of Chinese citizens.

A second kind of democratic deficit facing a revised PCSP pertains to political equality.

As we explained in section 6 , some civil society actors might simply pursue a hidden agenda, with the aim of lobbying international institutions in favour, for instance, of large corporations and other powerful social groups. Militarily, economically or culturally powerful people might find better advocates among civil society organisations than less powerful ones. This might lead de facto to the exclusion of some people(s) who are already unrepresented by public actors, or, at least, to discrimination against them if they are less well represented by civil society actors than others.

The strategy to adopt depends, again, on complex institutional design that cannot but be contextual. Different institutions and different international-law making contexts require different measures to protect political equality. All of them, in any case, should be guided by one single aim: equalising the ultimate power of the people(s) affected by the decision. And one way to do that could be, for instance, setting up mechanisms of affirmative action, such as quotas for civil society actors that claim to represent weaker or invisible social groups, ensuring a more proactive selection of civil society actors allowed to intervene, or providing special resources for weaker civil society actors. Again, public actors, such as states and state-based IOs in particular, are the only guarantors of the fairness of the rules and institutions adopted in this context. Precisely for that reason, again, only a virtuous combination of those two types of actors can deliver the kind of democratic legitimacy that the MRM is committed to provide.

The final democratic deficit that a revised version of the PCSP should aim at fixing pertains to deliberative contestability.

As we explained in section 6, opening up international decision-making processes to civil society actors is not going to produce an automatic improvement in the deliberative quality of such processes. Depending, in particular, on what kinds of private actors are allowed to intervene, the roles they are attributed, and the rights and obligations they 
are allocated, their inclusion may end up improving or impoverishing the quality of the deliberation and the mechanisms of public contestation.

For that reason, once more, it is crucial to design institutions adequately and enact the relevant rules, rights and obligations for all actors involved, which is something that can only be done in a contextual way, depending on the relevant international institution and decision-making or law-making process. The focus should be, again, on what kinds of actors are allowed to intervene, and what kind of conditions or requirements are imposed on them. Similarly to what has been said regarding the two previous kinds of democratic shortcomings, the only thing the MRM may argue, at this very general level, is that those concrete procedures and sets of rules should always be designed so as to meet the requirements of democratic legitimacy. Civil society actors, for instance, may be allowed to intervene in international law-making processes, but their participation should be made conditional upon their capacity to advance genuine public deliberation and/or to contribute to the public contestation of such decisions and laws. Other motivations, such as lobbying, logrolling, or manipulating international institutions and decisions should be ruled out and sanctioned.

All these are just examples of how the PCSP could and should be adequately limited, circumscribed and regulated in order to make a legitimate contribution to international decision- and law-making and become a truly deliberative principle. The adequate refinement of the PCSP requires, at a fundamental level, the participation of public actors of all kinds. This is the reason why a correct re-interpretation or concretisation of the PCSP can only come with and from a refined version of the PSP. Only then can one hope to escape the respective shortcomings of the two types of actors, but also those they may cause to one another, and therefore to reach the purpose of a virtuous mutual adjustment of the two principles to the benefit of democratic legitimacy.

Importantly, then, the requirements and limitations imposed on civil society actors can only come from states and IOs acting upon the PSP. This should not be taken to indicate a relationship of hierarchy or authority of statist actors over civil society. The democratic shortcomings of the PSP, even alleviated through the revisions proposed in section 7.2, are indeed the ones that contribute to the democratic justification of the PCSP. They also constitute the main reason for supporting a model like the MRM, one that is grounded in the idea of multiple representation. The relationship between the PSC and the PCSP cannot therefore be one of absolute precedence or hierarchy. It should, rather, be approached as a relation of mutual reinforcement between different sources of authority. Its aspiration is to contribute to the legitimacy of the multiple representation of all people(s)' interests.

\section{Conclusions}

The present article addressed the question of the identity of the legitimate actors of international law-making from the perspective of democratic theory. So doing, it aimed at laying the groundwork for a more comprehensive theory of democratic representation in international law.

In a nutshell, the article argued that both statist actors, i.e. states and state-based/statelike international organisations, and civil society actors are and should be considered complementary legitimate actors of international law-making, at least under certain 
conditions. Of course, other scholars have considered those actors as being complementary before. Holders of the Statist Model have grown to value international law-making processes where state consent no longer applies on its own, while promoters of the Dualist Model consider the role of civil society as a way to overcome the shortcomings of states and IOs as sole representatives of people(s). None of those models has said much on the exact combination of those two sets of actors, however. The former mostly regard international civil society as embryonic and its role as purely remedial of the democratic shortcomings of the Statist Model, while the latter mostly defend a negative argument for the role of civil society actors in filling some of the representative and deliberative gaps left void by the Statist Model, without indicating how exactly civil society actors should work with statist actors in representing people(s) and enhancing democratic deliberation.

Unlike previous accounts, therefore, our model, coined the Multiple Representation Model, is based on an expanded, democratic understanding of the principle of state participation: it is specifically designed to overcome or palliate the democratic deficits of more common versions of the Principle of State Consent. Second, it endorses a qualified version of the Principle of Civil Society Participation, one that is more restrictive and more critical of the democratic defects of civil society actors than most of its current supporters. Finally, it reveals how the democratic strengths and deficits of both models are best approached as mirroring one another and need to be combined in a complex account of multiple representation, one that identifies a multiplicity of public and private actors on the state and civil society sides, does not give precedence to one side over the other, and mutually refines each of their underpinning principles so as to overcome their respective democratic shortcomings.

The proposed model of representation in international law-making should be of interest to democratic theorists and international lawyers alike. It broaches indeed one of the most vexed issues raised by the sources of international law, i.e. the participation of private actors in international law-making and what this implies for the legitimacy of international law. Instead of side-tracking the participation of civil society actors in that process as a sign of informality or, worse, 'softness' of international law, it is time to work on how best to deal with the multilevel and multidimensional nature of democratic representation in international law-making and on how to combine public and private actors in that process. Only in that way will we get a chance of improving the legitimacy of international law.

\section{Acknowledgements}

We would like to thank Miriam Ronzoni and an anonymous reviewer for extensive comments, as well as Thomas Christiano, Richard Bellamy, Cristina Lafont, Anne Peters, Juan Carlos Bayón, José Juan Moreso, Andrew Williams, Jonathan Kuyper, Martin O’Neill, Julio Montero, Paula Gaido, Roberto Gargarella, Thomas Bustamante and the other participants in the conference 'The Legal Philosophy of Global Constitutionalism' held at Pompeu Fabra University, Barcelona, on 15-16 June 2017, in the conference 'The Future of Republicanism. Liberal, Critical, Radical?' held in York on 26-27 June 2017 and at the 'Coloquio SADAF 2017. El futuro de la filosofía práctica' held in Buenos Aires on 9-11 August 2017. Many thanks also to Aurélie Galetto and Adrien Folly, research assistants at the University of Fribourg, for their help with the formal editing of the article. 